\title{
"A relational approach to the geography of innovation: a typology of regions"
}




\title{
$\oplus_{\circledast}|| R|E| A \mid$
}

Institut de Recerca en Economia Aplicada Regional i Pública Research Institute of Applied Economics

\section{Universitat de Barcelona}

\author{
Av. Diagonal, $690 \bullet 08034$ Barcelona
}

WEBSITE: www.ub.edu/irea/•CONTACT: irea@ub.edu

The Research Institute of Applied Economics (IREA) in Barcelona was founded in 2005, as a research institute in applied economics. Three consolidated research groups make up the institute: AQR, RISK and GiM, and a large number of members are involved in the Institute. IREA focuses on four priority lines of investigation: (i) the quantitative study of regional and urban economic activity and analysis of regional and local economic policies, (ii) study of public economic activity in markets, particularly in the fields of empirical evaluation of privatization, the regulation and competition in the markets of public services using state of industrial economy, (iii) risk analysis in finance and insurance, and (iv) the development of micro and macro econometrics applied for the analysis of economic activity, particularly for quantitative evaluation of public policies.

IREA Working Papers often represent preliminary work and are circulated to encourage discussion. Citation of such a paper should account for its provisional character. For that reason, IREA Working Papers may not be reproduced or distributed without the written consent of the author. A revised version may be available directly from the author.

Any opinions expressed here are those of the author(s) and not those of IREA. Research published in this series may include views on policy, but the institute itself takes no institutional policy positions. 


\begin{abstract}
The aim of this study was to devise a method for computing a composite indicator that measures the regional degree of exposure to external knowledge sources. On the basis of this indicator, we propose a typology of regions according to their potential capacity to access extra-local items of knowledge, which might help them to recombine complementary elements of such an asset to produce a higher number of new ideas. Building on various research streams that have been relatively independent to date, we summarize a nonexhaustive instrumental list of recent studies that motivates our approach and the construction of our complex indicator, which can be used to appraise the extent to which each region is in an optimal position to access external innovative resources.
\end{abstract}

JEL classification: B41, C8, O18, O31, O33, R0

Keywords: knowledge networking regions, knowledge diffusion, formal, informal, European regions.

Rosina Moreno. AQR Research Group-IREA. Department of Econometrics, Statistics and Spanish Economy. University of Barcelona, Av. Diagonal 690, 08034 Barcelona, Spain. E-mail: rmoreno@ub.edu

Ernest Miguélez. AQR Research Group-IREA. Department of Econometrics, Statistics and Spanish Economy. University of Barcelona, Av. Diagonal 690, 08034 Barcelona, Spain. E-mail: emiguelez@ub.edu

\title{
Acknowledgements:
}

Part of this work was carried out while Ernest Miguélez was visiting the Rotman School of Management at the University of Toronto (Toronto, Canada). The use of the School's facilities is gratefully acknowledged. Roberta Capello, Jordi Suriñach and the participants of the 51st European Regional Science Association Conference (Barcelona, 1 September 2011) provided insights on earlier versions of this project, which were of great help. Some of the data used in this project were compiled by CRENoS. Finally, we also acknowledge financial support from the Ministerio de Ciencia e Innovación, ECO2008-05314, the Knowledge, Innovation, Territory (KIT) - Programme ESPON 2013 (2010-2013), and Ernest Miguelez from the Ministerio de Educación, AP2007-00792. However, any mistakes or omissions are ours. 


\section{Introduction}

Agents do not create in isolation. Indeed, the production of innovation relies on the recombination of existing knowledge and ideas. Employees within a firm and across its different departments create and recombine ideas through a process of collective learning that is structured within the organization (Lorenz, 1996; March, 1991). Organizations produce innovations by combining existing knowledge that goes beyond the limits of their boundaries. In short, firms turn to external sources of ideas (Rosenkopf and Almedia, 2003) and their ability to recombine and exploit such knowledge is pivotal to boost their competitive advantage (Dosi, 1988; Singh and Agrawal, 2011). Cassiman and Veugelers (2006), among others, have consistently shown that complementarities between firms' internal R\&D activities and their external knowledge acquisition are strong predictors of performance.

Recognition of the critical role of knowledge flows, knowledge diffusion and knowledge recombination dates back to the well-known Marshallian externalities. Several decades later, endogenous growth models (Grossman and Helpman, 1991; Lucas, 1988; Romer, 1990) put knowledge spillovers at the forefront of the mainstream research agenda. Furthermore, during the nineties, empirical analysis from the geography of innovation (Feldman, 1994; Feldman and Audretsch, 1999; Jaffe 1986, 1989; Jaffe et al., 1993) and new economic geography models (Martin and Ottaviano, 1999) indicated the localized pattern of knowledge spillovers and their role in explaining both the high spatial concentration of economic activity and spatial differences in economic growth. Central to this reasoning is the assumption that corporate and public R\&D investment spills over to third parties in the form of an externality, but the ability to receive knowledge spillovers is influenced by distance from the knowledge source' (Audretsch and Feldman, 1996, p. 630).

Recently, scholars have started to claim that excessively close actors may have little to exchange after a certain number of interactions (Boschma and Frenken, 2010). Indeed, the production of ideas requires the combination of different -though related, complementary pieces of knowledge to be most effective. However, at some point, co-located agents may start to combine and recombine local knowledge that eventually becomes redundant and less valuable. As a result, processes of lock-in may begin to occur (Arthur, 1989; David, 1985). Conversely, firms looking for external sources of knowledge that lie beyond their own boundaries may find that the knowledge they require is available beyond the boundaries of the region (Bergman and Maier, 2009). This strategic behaviour increases the probability of gaining first mover advantages in the market for the focal firm (ibid.) and consequently for the region. Hence, if there are strong internal connections between firms within a given region, but weak external connections to other sources of knowledge, 'there is 
the risk of localism, which implies that a regional economy is unable to acquire and master external knowledge and is hence likely to be less innovative' (Fratsei and Senn, 2009, p.17). Thus, it is important to balance internal and external, local and nonlocal interactions, to ensure a satisfactory amount of adoption and creation of knowledge.

We build our empirical strategy on this idea and develop a method that tries to quantify to what extent actors in regions can access sources of knowledge that lie beyond the confines of their cluster. This puts regions in a better strategic position to potentially use extra-regional ideas in the production of innovations. In so doing, we expect to increase our understanding of why some regional economies become locked into non-dynamic development paths, whilst others seem able to reinvent themselves continuously (Martin and Sunley, 2006).

To the best of our knowledge, little attention has been paid to this issue from an academic or policymaking perspective. The case of Europe is a paradigmatic example. In spite of recent empirical evidence and the importance European policymakers place on interregional connections to build a coherent and integrated European Research Area (European Commission 2007, 2010), policy reports do not tend to consider the external dimensions of regional innovation (e.g. the Regional Innovation Scoreboard, 2009). We strongly believe that connections to external sources of knowledge are as important for regions as their scientific and technological base. Consequently, we aim to fill this knowledge gap.

In this paper, we describe a method for constructing a synthetic indicator able to identify the regions in the best (and worst) position to access sources of knowledge from beyond their boundaries. To do this, we feed from various research streams -geography of innovation, regional economics, innovation economics, regional innovation systems (RIS) literature, and we survey and discuss the most recent conceptual and empirical contributions. On the basis of this review, we conceptually model the ways in which organizations and other actors in regions access external-tothe-region pieces of knowledge. We suggest that two different regimes are at work: (1) informal interactions and unintentional relations arising from serendipitous encounters between actors who lie in close spatial proximity; and (2) formal, intentional relations based on coordinated and welldefined linkages between actors who might, or might not, be in close spatial proximity. Hence, we characterize regions in terms of the ways in which they can potentially access external knowledge. In short, our research will provide a method for quantifying regions' exposure to external knowledge through these two patterns. 
On the basis of the proposed method, we aim to develop a typology of regions according to their position in these two dimensions: regions in a superior potential position to build informal connections with the outside world -above the average, but lacking formal, intentional linkages (clustering regions); regions with numerous formal relations but potentially few informal connections (globalizing regions); regions that do not have an advantageous positions in either of these two dimensions (non-interactive regions); and finally, regions with values above the mean in both indices (knowledge networking regions). We apply our approach to a group of NUTS2 regions in 31 European countries (EU-27 plus Iceland, Liechtenstein, Norway and Switzerland).

The outline of the paper is as follows: Section 2 reviews some relevant conceptual and empirical studies on the idea that agents access external-to-the-region knowledge to avoid regional lock-in. In this section, we bring together dispersed, but related, literature. Section 3 develops in more detail our conceptual model of connectivity through the two dimensions outlined above, and examines in depth the concept of 'knowledge networking regions'. Section 4 describes the empirical approach taken here. Section 5 summarizes some remarkable findings and Section 6 presents conclusions and policy implications.

\section{Review of theoretical and empirical literature}

\subsection{Physical space and knowledge flows}

Most geography of innovation scholars have reiterated that the role of physical proximity in enhancing knowledge creation is critical to understand the uneven distribution of economic and innovation activities across space, as well as the major spatial differences in growth rates between regions, even within the same country. To recap, empirical studies in the geography of innovation (Feldman, 1994; Feldman and Audretsch, 1999; Jaffe 1986, 1989; Jaffe et al., 1993) and economic geography (Martin and Ottaviano, 1999) literature have established that knowledge produced by a firm is only partially appropriated by the producer itself, whereas part of this knowledge spills over to other firms and institutions, reducing in this way innovation costs of these other organisations, as shown by endogenous growth models (Lucas, 1988; Romer, 1986, 1990). Face-to-face interactions between employees (Allen, 1977; Krugman, 1991b), frequent meetings, monitoring of competitors (Porter, 1990), spin-offs, trust building (Glaeser et al., 2002) and the like, which are essential to the effective exchange of ideas, have been indistinctly taken to explain the mechanisms by which knowledge spills over as an externality. Due to the nature of these mechanisms and the highly contextual features of the knowledge that is transferred, knowledge barters are assumed to occur 
among members of a co-located community and, therefore, knowledge is considered to be spatially sticky.

To sum up, the hypotheses hold that a firm's insertion into a given cluster provides it with advantages that are not available to firms outside the cluster. Co-location creates an 'industrial atmosphere' (Becattini, 1979; Marshall, 1920) or 'local buzz' (Storper and Venables, 2004), where information flows, knowledge transfers and learning opportunities take place continuously in both organized and accidental meetings (Bathelt et al., 2004). A key point is that little effort is needed to participate in the buzz, i.e. flows are more or less automatically received by those who share the physical space (op. cit.).

Critical to this line of argument is the explicit differentiation between tacit knowledge and codified/explicit knowledge. Tacit knowledge is highly contextual, difficult to transfer and share across long distances and therefore better transmitted in the form of meetings and face-to-face interactions (Breschi and Lissoni, 2001a,b) that are facilitated most by co-location (Breschi et al., 2010). Codified/explicit knowledge may travel frictionless across the space by means of information and communication technologies. Tacit knowledge is therefore relatively immobile, which implies that actors can only share it when they have a similar social context. This social context is also assumed to be bound in space (Gertler, 2003).

These are undoubtedly pivotal elements within the literature. However, an important point has been made by several scholars from innovation economics and organizational science. In their view, two contradictory arguments explain the diffusion of knowledge and its spatial stickiness (Torré, 2008): (1) tacit knowledge is a public good and its appropriateness escapes the control of its producers, who cannot prevent others from benefitting from it; (2) because it is highly contextual, tacit knowledge needs frequent interactions to be transmitted. Objections to this contradictory logic have led researchers to show that co-location favours the transmission of knowledge, instead, via market mechanisms and pecuniary externalities across members of the same epistemic community, including local networks (vertical and horizontal) and local mobility of the labour force. These transmission methods have nothing to do with pure knowledge externalities (Almeida and Kogut, 1997, 1999; Breschi and Lissoni, 2009; Camagni and Capello, 2009; Rychen and Zimmermann, 2008; Torré, 2008; Zucker et al., 1998). Thus, spatial proximity is not a necessary or sufficient condition for knowledge to flow across agents (Boschma, 2005). In contrast, social and other forms of non-spatial proximity, which are in the very nature of the relationships between members of the same epistemic community, are essential. As a result, highly contextual knowledge might not be as spatially sticky as is usually assumed in the geography of innovation literature, if other types of 
proximity are also at work. As we will discus in more detail in Section 3, the reality probably lies somewhere between these two approaches. Thus, pure localized knowledge externalities may still play a role (Iammarino and McCann, 2006), especially in the early stages of an industry life cycle (Audretsch and Feldman, 1996).

\subsection{From localization to a balanced internal-external mix of knowledge flows}

Indeed, an increasing number of academics have called into question the widely accepted assumption that knowledge flows are that localized. This assumption, they argue, might have limited our understanding of the ways in which knowledge flows across space (Coe and Bunnell, 2003). Certainly, recent empirical evidence casts doubts on the orthodox viewpoint outlined above. Some studies have started to explore the influence of extra-local knowledge sources on firms' innovative performance, though the results are ambiguous. For instance, in their analysis of the Boston biotech community, Owen-Smith and Powell (2004) showed that while membership to local networks, rather than centrality within these networks, was a conduit to better company performance, central positions in geographically dispersed networks increased firms' patent volume. Thus, 'being situated at the intersection of numerous formal pipelines enhances firm-level knowledge outputs' (op. cit., p. 16). Gittelman (2007) suggested that geographical proximity matters for innovation, but opportunities for learning by interacting also exist beyond regions' boundaries in the case of US biotech firms. Indeed, he estimated that distant research teams received more citations of their output than teams formed in closer proximity. In parallel, Gertler and Levite (2005) found that the most successful Canadian biotech firms are externally oriented. Thus, patenting Canadian biotech firms are more likely to have foreign partners in their collaborative projects than their non-patenting counterparts. This suggests that the best places for biotech innovators are not only those with a strong 'local buzz', but also regions that are well connected extra-locally.

Trippl et al. (2009) analysed the software cluster in Wien. It was found that the local context remains highly relevant as a source of knowledge and information, but extra-local connections (national and European customers, suppliers, competitors, and service companies) also play an important role. The authors concluded that the interplay between local, national and global seems to drive innovation-oriented firms in the software industry. Similar conclusions were drawn in Giuliani and Bell (2005) for the case of a Chilean wine cluster. According to the authors, two types of behaviour characterize knowledge dynamics in this cluster: (1) although local linkages are prominent, they are highly selective, rather than unstructured and unplanned; and (2) for some firms, learning links are partially or almost exclusively found outside the cluster. Further examples 
are case studies by Asheim and Isaksen (2002), who analysed three Norwegian clusters (shipbuilding, mechanical engineering, and electronics). They found external-to-the-region contacts to be crucial in the innovation process of firms. As the authors pointed out, firms in clusters tend to exploit both place-specific resources and external knowledge sources to increase their innovation rates. Similar conclusions were made by Vang and Chaminade (2007) in a study of Toronto's film industry and by Belussi et al. (2010) in a paper on life science firms in the Emilia Romana region (Italy).

In a similar vein, Rosenkopf and Almedia (2003) convincingly argued that, in spite of the larger pools of knowledge available at local level, firms need to search for knowledge sources beyond their geographical and technological vicinity as the distant context may offer particularly useful ideas and insights for recombination. Using data on patents, citations, inter-firm alliances and labour mobility, the aforementioned authors evaluated various knowledge inflows at different spatial scales. Despite their claims, the positive effects of distant relationships (in the form of alliances and mobility) were not supported by the data. Simonen and McCann (2008) drew similar conclusions in a different context. Their study on inter-firm labour mobility in a sample of Finish firms shows that labour inflows from the same area are positively related to firms' innovative performance. Meanwhile, outside-the-region inflows are only related to firms' performance when the incoming worker belongs to high-tech sectors that are similar to the focal firm. Boschma et al. (2009) found similar results for Swedish firms. They argued that the positive effects of employee inflows might depend on the skills portfolio of the incumbent workers, as well as on whether or not they come from the firm's geographical area. Therefore, they split inflows according to the employees' skills (i.e. similar, related, and unrelated skills). They found that both related and unrelated skills had a positive effect when incumbent workers come from the firm's own area, whilst only related skill inflows had a positive impact in the case of extra-local workers. Their explanation is based on the following logic: incumbent workers with very similar skills to the receiving firm do not add any value to its current knowledge base, whilst workers with different, but related, skills do contribute to firms' performance even if they move in from a different spatial context.

This empirical evidence goes hand in hand with an increasing number of claims from prominent academics who have raised concerns in this area. Thus, several scholars have lately stressed the need for firms to network with extra-local knowledge pools to overcome potential situations of regional 'entropic death', 'lock-in' or 'over-embeddedness' (Boschma, 2005; Camagni, 1991; Grabher, 1993; Uzzi, 1996). These claims have contributed to a lively current debate among research streams about the conditions in which tacit knowledge can be transmitted at a distance and go beyond a region's confines, as well as the extent of such transmission. Indeed, it has been 
argued that two very close actors may have little knowledge to exchange and that innovative production usually requires the combination of dissimilar, but related, complementary knowledge (Boschma and Frenken, 2010; Boscham and lammarino, 2009). ${ }^{1}$ Thus, as time passes and local interactions lead to the combination and recombination of the same pieces of knowledge, organizations end up stuck in strong social structures that tend to resist social change (Boschma and Frenken, 2010; Morrison et al., 2011) and prevent them from recognizing opportunities in new markets and technologies (Lambooy and Boschma, 2001). Thus, 'distant contexts can be a source of novel ideas and expert insights useful for innovation processes (...). Firms therefore develop global pipelines not only to exchange products or services, but also in order to benefit from outside knowledge inputs and growth impulse' (Maskell et al., 2006, p. 998). As already asserted in the social network literature, non-redundant rather than repeated ties are the most apposite to increase knowledge flows and innovation (Burt, 1992; Granovetter, 1973).

Truly dynamic regions in the era of the knowledge economy are therefore characterized not only by dense local learning and interaction, but also by the ability to identify and establish interregional and international connections to outside sources of ideas (Gertler and Levitte, 2005; Maskell et al., 2006). Thus, certain actors within dynamic regions can build connections with more or less remote actors, to form non-redundant ties that bring new knowledge into a given local network (Burt, 1992). These actors function as knowledge gatekeepers, setting up global bridges between the local network and outside sources of knowledge (Glucker, 2007). Thus, they introduce knowledge variation into the regional economy, which can prevent the region from entering non-dynamic development paths. In sum, regions that host globally connected organizations end up being more successful than others (Bergman and Maier, 2009).

Analogously, the regional innovation system (RIS) literature (Autio, 1998; Cooke et al., 2000) has generally looked at regions in an isolated manner, that is, without any specific consideration of interrelationships across regional systems or on larger spatial scales. However, recent contributions within this stream have also started to tackle this issue (Tödtling and Trippl, 2005). Indeed, external links provide access to ideas and technologies that are not endogenously generated within the regional system, which is actually far from being self-sustained (op. cit.). In consequence, recent works have suggested the concept of "Open RIS" (Belussi et al., 2010).

\footnotetext{
1 Note that, as stressed in Boschma and lammarino (2009, p.295), 'extra-regional knowledge that is complementary, but not similar, to existing competences in the region will particularly enhance interactive learning. (...). If the external knowledge is unrelated, the industrial base of the region cannot absorb it and is unlikely to benefit from it. When the external knowledge is the same (...), it can be absorbed locally, but the new knowledge will not add much to the existing local knowledge base'. As we will show later on, our empirical application does not consider this distinction, which is left for future extensions.
} 
Following on from part of these theoretical and empirical contributions, Bathelt et al. (2004) envisage a conceptual model that is concerned with the coexistence between a vibrant 'local buzz' and a number of 'pipelines' that provide access to relevant pools of knowledge outside the 'buzz'. These authors hint at the fact that in reality firms build pipelines to benefit from knowledge hotspots around the world, and do not build their knowledge stock solely from local interactions (Bahlmann et al., 2008). The logic in Bathelt's et al. (2004) implies that ${ }^{2}$ : (1) new (tacit) knowledge is created around the globe and firms that can access it through global pipelines gain competitive advantage; (2) this knowledge acquired from abroad may spill over or be transferred within the local cluster through the local network of a firm or individual; consequently (3) there is a kind of trade-off between 'a too much inward-looking and a too much outward-looking' structure of grabbing knowledge (Bathelt et al., 2004, p. 46); and (4) there are limits to the number of pipelines a firm can manage at the same time, and therefore it is better to have several firms managing a set of pipelines than for one large firm that manage a high, but limited, number of pipelines. Pioneering contributions along these lines were made, however, by Hägerstrand (1965), who distinguished between contagious and hierarchical patterns of information diffusion. In the contagious diffusion regime, information flows first at close proximity from the originating source, then with effort at greater distances. According to the hierarchical regime, information first diffuses from relatively large cities to other equal-sized cities, even those at large physical distances, between which communication infrastructures are supposed to be more developed. Maggioni et al. (2007) and Maggioni and Uberti (2011) took these insights into account and developed an extensive research agenda based on the distinction between unintended cross-regional spatial spillovers and intentional relations based on a-spatial networks. Their logic is straightforward: knowledge is created in central organizations that tend to co-locate. Subsequently, knowledge is diffused either through a trickle down process of spatial contagion of neighbouring regions (by means of face-toface interactions and other 'unintended' means) or through a-spatial networks structured in the form of contractual agreements between organizations that connect clusters, irrespective of the spatial distance between them.

Tödtling et al. (2006) and Trippl et al. (2009) use a broader set of dimensions to classify the ways in which knowledge flows within and between clusters and regions. For these authors, knowledge diffusion processes can be summarized by differentiating between two dimensions. The first dimension distinguishes between traded and untraded interdependencies (following Storper, 1997) on the basis of whether or not there is monetary or similar compensation. The second dimension

\footnotetext{
2 Note that in their model they allow the scope of the 'local buzz' to go beyond the limits of the administrative region into neighbouring regions that might totally or partially belong to this same 'buzz'. In contrast, 'pipelines' are established with actors located at a distance. Moreover, whereas information inflows within the 'local buzz' do not require a major effort as they are more or less automatically received, the construction of 'pipelines' requires a conscious, intentional commitment to identify potential partners and build formal relations.
} 
distinguishes between static and dynamic knowledge exchanges, that is, respectively, transfers of pieces of already available knowledge or barters that involve interactive learning processes between agents (see also Capello, 1999).

As we will see in more detail in Section 3, our conceptual framework is based on these early contributions, though some differences will be worth mentioning.

\subsection{Do regions 'pipe' external knowledge? Some evidence at regional level}

Within regional science, the number of studies that address cross-regional relationships and their impact on economic outcomes has sharply increased in the last 25 years. A clear example is the growing number of papers that apply spatial econometric techniques at regional level. These papers have been more or less concerned with estimating cross-regional knowledge externalities in knowledge production function (KPF) frameworks (Acs et al., 1994; Anselin et al., 1997; Bottazzi and Peri, 2003). Indeed, as stated by prominent scholars, there is no reason to assume that knowledge stops flowing because of regional borders (Audretsch and Feldman, 2004; Krugman, 1991a). Therefore, spatial econometric techniques and the spatial weight matrix have notably improved the way such externalities are measured (Autant-Bernard and Massard, 2009). Admittedly, this approach is no more than a corollary of the traditional localized knowledge spillovers (LKS) story, although it considers that externalities may spread to regions in the immediate vicinity.

Other studies within this stream have tried to go one step further. Moreno et al. (2005) and Parent and LeSage (2008), among others, have exploited the concept of technological proximity between regions vis-à-vis spatial proximity in estimates of cross-regional externalities. Their underlying logic relies on the idea that knowledge externalities flow easily among members of epistemic communities of scientists and technicians in highly specialized technological fields, irrespective of their geographical location, due to the fact that they share a specific knowledge background and common jargon and codes. Similarly, Kroll (2009) and Ponds et al. (2010) have built weight matrices using collaborative research data across regions to proxy the social distance between them at aggregate level. In this way, they show the importance of reflecting non-spatial, more meaningful measures of proximity across regions in estimations of the effects of cross-regional knowledge flows on regional innovative performance. The aforementioned study by Maggioni et al. (2007) follows a similar approach, as spatial contagious effects vis-à-vis network effects in the form of research collaborations are estimated in a spatial KPF framework. However, their approach 
reveals that when the spatial weight matrix is subtracted from the network matrix and a pure social matrix is considered on its own, important spatial effects are unaccounted for.

In spite of these and other contributions, the literature on cross-regional knowledge diffusion and regional innovation is relatively scant, apart from studies on the purely spatial approach. Likewise, supra-national organizations' policy reports on regional innovation do not tend to consider that extra-regional linkages are part of the regional innovation performance, either from an input or output perspective. For instance, the latest Regional European Scoreboard (2009) takes into account a number of regional innovation indicators, such as human capital, R\&D expenditure, ICT penetration, employment in high technologies and patents. However, it does not include indicators concerning a region's degree of openness to external sources of knowledge, in neighbouring or distant regions, that may have a definite impact on regional innovative output and, subsequently, on economic development. By means of principal component analysis, the Regional Innovation Monitor (European Commission, 2011) produces a typology of innovative regions using several indicators, including public and private R\&D, patents, population with tertiary education. None of these indicators appraise a region's capacity to access and use external knowledge in its innovation processes. Similar approaches are followed by the Global Innovation Index (INSEAD, 2011), the OECD (Marsan and Maguire, 2011) and Navarro et al. (2009). Only recently, in its annual assessment of the performance of regions (OECD, 2009), the OECD included co-patenting with external-to-the-region inventors as an indicator of knowledge sharing.

Similarly, regional innovation datasets $\left(O E C D^{3}\right.$ or Eurostat $\left.{ }^{4}\right)$ barely reflect the relational dimensions of regions as entities that establish relationships through their actors that usually go beyond the regions' boundaries and are beneficial for their innovative performance, as they are their human capital or R\&D efforts.

In consequence, we believe that the approaches that are currently used to assess the innovation performance of regions are far too simplistic. Our research project tries to fill this gap by proposing a method for computing a composite indicator that evaluates the extent to which regions can access external pieces of knowledge and information, either by a process of informal barters between agents located in neighbouring regions or by means of formal linkages with outsiders. Subsequently, our strategy will provide a taxonomy of regions that is based on the mechanisms for accessing external knowledge: formal versus informal interactions.

\footnotetext{
3 http://stats.oecd.org/Index.aspx?datasetcode=REG DEMO TL2.

4 http://epp.eurostat.ec.europa.eu/portal/page/portal/region cities/regional statistics/data/main tables.
} 


\section{Towards the 'knowledge networking region'}

The above review helps us to build a conceptual framework for the 'knowledge networking region' notion, which we develop in the present section. Again, our primary aim in this paper was to develop a simple method for appraising the external dimension of regional knowledge production. In doing so, we obtain an instrument for classifying regions into different tiers, according to their capacity to access external sources of knowledge and innovation. To achieve this, we distinguish between two ways in which regional agents access external knowledge. As outlined above, the approach chosen at this stage resembles that of Bathelt et al. (2004) and Maggioni et al. (2007). Thus, actors access external knowledge pools by means of two distinct patterns, i.e.

- an informal, non-intentional, serendipitous pattern of knowledge interactions that take place between agents located in spatial proximity and

- a formal, intentional, and conscious pattern of linkage formation between actors, irrespective of their geographical location.

Below, these two patterns are illustrated in detail. Note that our distinction has nothing to do with the usual classifications, such as tacit (assimilated to informal) vs. codified (assimilated to formal) knowledge. Again, the tacit property has been widely advocated as the reason why knowledge of this type is easily transmitted by means of face-to-face contacts, and therefore co-location is required (Breschi and Lissoni, 2001a,b). However, several authors stress that even when knowledge is totally codified, what is required is a tacit understanding of the message that is transmitted, which is a property of the epistemic community and may have little to do with the territory in which the knowledge is produced (Breschi and Lissoni, 2001a,b; Cowan et al., 2000; Steinmueller, 2000). Note also that our attention is totally focused on the dichotomy between informal/formal mechanisms, rather than whether the linkages are in neighbouring regions or not. In this way, we allow for cross-regional formal knowledge flows between contiguous regions. Finally, among the formal cross-regional linkages considered, we include collaborations between actors, as in many previous studies. However, we also include geographical mobility of highlyskilled labour and access to codified knowledge located outside the region. Bearing this in mind, we will now describe in detail the logic behind each of the patterns of regional capacity to access external knowledge. 


\subsection{Informal pattern of knowledge diffusion}

Co-location brings people together, facilitates contacts for information and enhances the exchange of knowledge. In other words, agents who are spatially concentrated benefit from knowledge externalities. In this case, the producer of a given piece of knowledge cannot internalize all its effects and part of it spills over to other agents, who do not compensate the initial producer. These kinds of knowledge flows occur via informal face-to-face interactions, monitoring of competitors, advisor-student relationships, and so on. Just being in a location is enough to contribute to and benefit from continuous flows of information and updates, gossip, news, rumours, and recommendations (Bathelt et al., 2004; Gertler, 1995).

As we discussed in previous sections, empirical studies tend to confirm that knowledge externalities are geographically bound, in which no other forms of proximity are necessarily involved. The transfer of knowledge takes place without explicit coordination between agents. Thus, firms near knowledge sources show better innovative performance than firms located elsewhere (Audretsh and Feldman, 1996). In many instances, the administrative boundaries of a region do not coincide with the boundaries of the 'local buzz'. When the sender and the receiver of the externality are not located (sometimes by chance) in the same region, spillovers across regions occur.

As already stated, the spatial economics and econometrics literature has long dealt with the estimation of cross-regional knowledge externalities in a KPF framework (Acs et al., 1994; Anselin et al., 1997, among many others). For instance, well-known studies on Europe have estimated the spatial scope of knowledge spillovers to be around 250-300 km (Bottazzi and Peri, 2003; Moreno et al., 2005). ${ }^{5}$

Needless to say, the informal pattern of interaction described here does not measure knowledge externalities per se. In fact, knowledge spillovers are invisible (Krugman, 1991a), although they may sometimes leave a paper trail (Jaffe et al., 1993). The variables chosen in our analysis only let us assess the extent to which each region is well positioned to endorse informal interactions and serendipitous encounters that may encourage knowledge diffusion between actors of neighbouring regions. What is actually measured, as in the literature, is the potential for localized spillovers (D'Este and lammarino, 2010). Whether or not knowledge indeed flows across regions is an

\footnotetext{
5 These estimations imply that spillovers are very likely to cross administrative borders, even at the level of NUTS2 regions and in countries in which this aggregation level translates into large regions, such as Spain.
} 
interesting question, which goes beyond the scope of the present analysis. ${ }^{6}$ The following variables could be used to proxy the advantageous position of regions that may receive knowledge flows from informal interactions:

- R\&D expenditure in neighbouring regions: R\&D is well established as being the greatest source of new knowledge (Arrow, 1962) and a source of spatial informal knowledge exchanges through pure externalities (Jaffe, 1986, 1989). Thus, cross-regional R\&D externalities have been widely investigated (Anselin et al., 1997; Bode, 2004; Bottazzi and Peri, 2003).

- Patent applications in neighbouring regions: patent applications have been used as an indicator of R\&D productivity at regional level. Therefore, patent applications in neighbouring regions can be used as an indicator of potential informal access to knowledge from innovation outputs (Autant-Bernard and LeSage, 2011).

- Human capital in neighbouring regions: theoretical and empirical contributions have shown the existence of human capital externalities (Lucas, 1988; Moretti, 2004; Rauch, 1993), arguing that skilled individuals tend to be more productive when they are surrounded by their peers. Though studies regarding cross-regional informal flows from human capital stocks are less preponderant, human capital externalities may well go beyond the boundaries of the administrative region.

\subsection{Formal pattern of knowledge exchange}

In recent years, several authors have pointed out that, even at close spatial proximity, knowledge flows are not automatically received just by 'being there', as previous literature tends to assume. Rather, knowledge flows follow specific transmission channels, which are mainly based on market interactions (Breschi and Lissoni, 2001a,b). In some instances, actors look for external-to-the-firm pieces of knowledge in knowledge pools that lie beyond the boundaries of their own region. Thus, some members of a region can activate linkages with these pools. As reviewed in Section 2, such linkages are pivotal to access external pieces of ideas and information that would otherwise not be available for the local cluster.

These members therefore play the role of 'knowledge gatekeepers'. This figure is derived from the concept of 'technological gatekeeper', proposed by Allen (1977). Knowledge gatekeepers make a conscious effort to establish formal linkages with knowledge hotspots outside the region,

\footnotetext{
${ }^{6}$ Yet, the ability of actors within regions to absorb, understand and take advantage of incoming spillovers might also be dependent on their absorptive capacity (Cohen and Levinthal, 1990).
} 
irrespective of the geographical distance. Contrary to informal knowledge diffusion mechanisms, the links that are built are not automatic and participation in them is not free. Their establishment requires a costly process. Gatekeepers take the role of global bridges (Glucker, 2007) that link the 'local buzz' with external knowledge sources, thus covering 'structural holes' between networks (Burt, 1992). For a knowledge gatekeeper to be effective for the region as a whole, it has to be inserted in global networks and well-embedded in the 'local buzz' through which the incoming insights are diffused. If this is the case, the more connected a gatekeeper is with external partners, the more potentially connected the region will be with distant pools of knowledge, and therefore the higher the probability of gaining competitive advantages in the market, both for the focal firm and for the entire region (Bergman and Maier, 2009).

This knowledge transfer, which can take place across large distances (although not exclusively), requires other forms of proximity to be effective. Other dimensions of proximity (such as social, cognitive, institutional and organizational) are key in understanding interactive learning and diffusion of knowledge between partners that are located at a distance (Boschma, 2005). ${ }^{7}$

Naturally, a large number of connections between agents and external sources of knowledge does not ensure that the knowledge will enter and spread into the region. Ultimately, this will depend on the absorptive capacity of the gatekeeper (Cohen and Levinthal, 1990) and, more importantly, on whether or not this gatekeeper is willing to share its knowledge within the 'local buzz'. If the connected agents behave as external stars (Morrison et al., 2011), then the region as a whole will not benefit from their external connections.

Like Bathelt et al. (2004) and Maggioni et al. (2007), we believe that alliances between organizations are critical to build 'pipelines' with outsiders. However, as in Boschma et al. (2009), we extend the formation of external linkages to the issue of the geographical mobility of knowledge workers who embody tacit knowledge (see also Coe and Bunnell, 2003; Rosenkopf and Almedia, 2003). The capacity of particular agents to connect with external sources of codified knowledge is also considered. In sum, the following measures may proxy for these formal linkages:

- Cross-regional co-patents. Networks of inventors are a source of potential knowledge flows, as individuals connected within a collaborative framework are more willing to learn from each other than isolated inventors (Breschi and Lissoni, 2004, 2009; Cowan and Jonard, 2004; Gomes-Casseres et al., 2006; Singh, 2005).

\footnotetext{
${ }^{7}$ See also previous studies by the French School of Proximity (for a thorough review of this literature, see Carrincazeaux et al., 2008).
} 
— Inflows of inventors. Mobility may also favour knowledge diffusion. The movement of skilled individuals across locations contributes to knowledge mobilization throughout the space. Skilled workers take their knowledge with them and share it in a workplace with their new employer and colleagues. In return, they acquire knowledge from their new colleagues and, in general, promote new combinations of knowledge (Laudel, 2003; Trippl and Maier 2010).

- Citations made to outside-the-region patents. We use this proxy as it indicates the extent to which regional actors rely on already codified sources of knowledge that go beyond regional boundaries. Patent citations have been used widely in studies of innovation to measure the scope of knowledge flows (Jaffe et al., 1993, Peri, 2005).

\subsection{A simple typology}

In short, up to six variables (three for each regime) are assembled to approximate the extent to which a region can take advantage of cross-regional knowledge diffusion.

The computation of the two sub-indices will shed some light on each region's specialization pattern, in terms of its level of connectivity with external knowledge. Combinations of regions' specialization in one regime or the other will produce the following typology:

- Clustering regions: regions showing higher than average values for potential informal linkages but lower than average values for formal linkages.

- Globalizing regions: regions characterized by lower than average values for informal linkages but higher than average values for formal linkages.

- Non-interactive regions: regions showing lower than average values for both indicators.

- Knowledge networking regions: regions showing higher than average values for both synthetic indicators: informal and formal linkages.

Figure 1 graphically summarizes the suggested typology. In a nutshell, 'knowledge networking regions' are regions that are in a relatively advantageous position to receive and access external pools of knowledge through the two patterns illustrated in the previous sections.

[Insert Figure 1 about here] 


\section{Empirical approach}

Below we summarize the result of applying the method outlined in the previous section to a group of 287 NUTS2 regions belonging to 31 European countries (EU-27 plus Iceland, Liechtenstein, Norway and Switzerland). See the Appendix for the complete list of countries.

\subsection{Variable construction}

With respect to the construction of the indicator of a region's capacity to access knowledge through informal interactions we consider the following variables:

- R\&D expenditure in neighbouring regions (R\&D expenditure weighted by a pre-defined spatial weight matrix): average value of $R \& D$ expenditure in the neighbouring regions.

- Patent applications in neighbouring regions (patent applications weighted by a pre-defined spatial weight matrix): average value of patent applications in the neighbouring regions.

- Human capital in neighbouring regions (percentage of population aged 15 and over with tertiary education over the total population, weighted by a pre-defined spatial weight matrix): average value of human capital in the neighbouring regions.

The spatial weight matrix taken from the spatial econometrics toolkit will help us to construct this sub-indicator. This is a non-stochastic square matrix that captures an ad-hoc intensity of the interdependencies between each couplet of regions, where $W=\left\{w_{i j}\right\}$, leading to a definition of 'neighbouring'. The most usual definition of neighbouring is the first order physical contiguity, that is, if two regions share the same administrative border $w_{i j}=1$, and $w_{i j}=0$ otherwise. In this paper, we use a more complex version of this matrix, which takes the physical distance between regions' centroids, instead of contiguity, as a neighbouring criterion and introduces strong spatial decay, giving far more importance to short-distance neighbours than to long-distance neighbours. Concretely, we define $w_{i j}=\exp \left(-0.01 d_{i j}\right)$, where $d_{i j}$ is the Euclidean distance, in kilometres, between the centriods of region i and region j. Following Bottazzi and Peri (2003), a cut-off of 300 $\mathrm{km}$ is introduced. ${ }^{8}$

\footnotetext{
${ }^{8}$ Other distance decays have been tried, such as $0.02,0.03,0.04,0.05,0.06,0.07,0.08,0.09$, and 0.10.
} 
The proxies used to construct the indicator that capture formal interactions include:

- Co-patents with other regions: the valued degree centrality of cross-regional co-patents. The number of patents co-authored with inventors from outside the region. When a patent involves inventors whose addresses are in different regions, we assume that cross-regional collaborations took place. We 'full-count' all the collaborations across regions, irrespective of the number of inventors reported in each patent. For each patent with multiple inventors, all possible pairs of regions ij were created.

- Inflows of skilled workers: valued in-degree centrality of cross-regional inflows of inventors. Number of inflows of inventors from other regions. A 'mobile' inventor is broadly defined as an individual who moves across different regions, irrespective of whether the focal individual changes his employer or not. Mobility is computed through observed changes in the inventor's region of residence, as reported in the patent documents. ${ }^{9}$ Admittedly, in this manner we only capture mobility if the inventor applies for a patent before or after a move, which probably underestimates real mobility. We compute the movement in time between the origin and the destination patent, but only if there is a maximum lapse of 5 years between them.

- Cross-regional patent citations: valued in-degree centrality of cross-regional patent citations. Number of citations made to patents of other regions.

The socio-matrix, taken from social network analysis (SNA), is used to build the variables that make up this indicator. This is a tabular representation in matrix form that measures social relationships between the members of a network. Networks are formed by actors, or nodes (regions in our case), which are connected to one another by means of relations or ties. These connections form relationships between nodes that can be represented in the socio-matrix, whose elements capture the intensity of the relationship between node i and node j. Relations in a network might be undirected when the relationships are symmetric, or directed when the direction of the relation between a given pair of points does matter. Additionally, the relations between nodes might be binary ( 1 when a relationship exists, and 0 otherwise) or valued (the intensity of the relationship matters and numerical values are 'attached' to each of the lines). One of the most important point measures in SNA is that of degree centrality. The aim is to detect the most central (i.e. the most popular) actor within the structure. This is defined as simply the number of incumbent linkages that a given node has. When networks are directed, the degree centrality may include separately in-

\footnotetext{
${ }^{9}$ Note that a single ID for each inventor and anyone else involved is missing. Hence, to compile the mobility history of inventors, we need to identify them individually by name and surname, as well as via other useful information contained in the patent document. Data cleaning and parsing, name matching, and name disambiguation are the different stages undertaken to single out who is who in these patents, see Miguélez and Gómez-Miguélez (2011).
} 
degree centrality (the number of edges directed to the vertex) and out-degree centrality (the number of edges that the vertex directs to other vertices).

Using the different variables suggested and the corresponding instruments, we compute a single measure that allows us to assert whether or not a given region is a knowledge networking region. In addition, we obtain a composite indicator for the formal linkages dimension and another for informal linkages.

Both synthetic indicators corresponding to each dimension are developed following the procedure used in the European Innovation Scoreboard (2009). Specifically, since the indicator variables we are using for the two different categories of linkages can be highly volatile and have skewed data distributions (where most regions show low performance levels and a few regions show exceptionally high performance levels), data will be modified firstly using a square root transformation. Secondly, based on the square root values, rescaled values are obtained by subtracting the minimum value and then dividing by the difference between the maximum and minimum value. The maximum rescaled score is thus equal to 1 and the minimum rescaled score is equal to $0 .{ }^{10}$ For each kind of linkage (informal and formal) a composite indicator is calculated as the unweighted average of the rescaled scores for all indicators within the respective dimension. In sum, knowledge networking regions are regions above the European average in terms of specialization on both types of linkages.

\subsection{Data sources}

The raw data corresponding to informal knowledge diffusion variables (R\&D expenditure, patents, and human capital) were assembled by CRENoS, using manifold data sources: Eurostat, OECD REGPAT database, ISTAT and the Institut National de la Statistique et des Études Économiques. A summary of data sources can be found in Table 1, where the time span considered for each variable is also reported.

[Insert Table 1 about here]

\footnotetext{
10 To determine the maximum and minimum scores in the normalization process, we exclude outliers. Positive outliers are identified as values that are higher than the average plus 2 times the standard deviation. Negative outliers are identified as values that are lower than the average minus 2 times the standard deviation.
} 
The data source for the formal knowledge exchange variables was the OECD REGPAT database (January 2010 edition). The OECD citations database (January 2010 edition) was used for the cross-regional citations. A socio-matrix was built for each of the variables, and degree centrality (or in-degree centrality) measures were calculated.

Population data from Eurostat was used to normalize all six measures to the size of the region (see Table 1 again).

We are completely aware of the caveats of using patent data in economic analysis. For instance, it is well known that not all inventions are patented, they do not have the same economic impact, and not all patented inventions are commercially exploitable (Griliches, 1991). Additionally, it is known that firms frequently patent for strategic reasons, to build up a patent portfolio to improve their position in negotiations or their technological reputation (Verspagen and Schoenmakers, 2004). Equally, the socio-matrices that were built reflect, to some extent, either the innovation capacity of regions, the degree of decentralization of innovation activity in the different national states, or the different sectoral specializations in regions, which in turn determine the regional propensity to apply for patents (pharmaceuticals and biotech firms have an above average patent propensity). ${ }^{11}$ Bearing these shortcomings in mind, we still find the empirical analysis worthwhile.

\section{Results}

We built both sub-indicators using the procedure described above. Figure 2 shows the scatter plot of the sub-indicators that were computed. Clearly, a strong positive relationship arose, as the correlation coefficient is 0.73 . Note that the majority of the regions were either non-interactive (113) or knowledge networking regions (118). Meanwhile, only 41 regions were clustering regions, and 15 were globalizing regions. Clearly, there seems to be a relationship between both sub-indices. We believe that this relationship is not accidental. Whether or not there is a causal relationship between the two sub-indices or the direction of this causality are interesting questions which are beyond the scope of the present analysis, though.

[Insert Figure 2 about here]

Figure 3 maps the spatial distribution of the four categories of regions considered. A short description of each type of region is given below, based on Figures 2 and 3.

\footnotetext{
11 See Ter Wall and Boschma (2009) for a discussion of additional shortcomings of using patents in regional analysis, and Lenzi's (2010) awareness of the use of inventors identified through patents.
} 
Clustering Regions. We computed that 41 regions out of 287 could be labelled as clustering regions. These are regions that are located in relatively close proximity to other highly innovative regions (in terms of $R \& D$, patents and human capital) and therefore can potentially receive informal knowledge flows governed by physical distance. However, and more importantly, these regions lack a critical number of formal, intentional knowledge linkages with external sources of knowledge. Amongst them, we identified regions in the centre of Spain and north of Italy, some French regions close to Paris and Germany, some regions in the north and west of England, part of Ireland, and the regions of southern Norway. To sum up, the Clustering regions seem to belong to the EU15 and are close to core regions that are both informally and formally specialized. Broadly speaking, they are low-to-medium technologically advanced regions that, by happy chance, are located physically near to knowledge poles and are therefore dragged into innovative activities by their innovative neighbours.

Globalizing Regions. We computed that 15 regions out of 287 were labelled as globalizing regions. These regions are well connected by formal linkages to external areas, in spite of being relatively physically isolated from other innovative regions. Broadly speaking, these regions tend to perform notably better than clustering regions in terms of innovation activity. The list includes 1 German region (Dresden), 4 French regions (Île de France, Bourgogne, Provence-Alpes-Côte d'Azur and Bretagne), 2 British regions (East Anglia and North Eastern Scotland), Emiglia Romana in Italy, Trondelag in Norway, Wien in Austria, Pohjois Suomi in Finland, 2 Swedish regions (Vaestsverige and Örve Norrland) and 2 Slovenian regions (Zahodna Slovenija and Vzhodna Slovenija). Note that 2 of these 15 regions contain important capital cities, e.g. Paris and Wien. This kind of region acts more intensely as a regional knowledge hub, since it is connected to external knowledge sources by means of formal relations, and enables actors in nearby regions to access knowledge by means of a contagious process of informal interactions. This is particularly true for the two aforementioned capitals.

Non-interactive Regions. We computed that 113 regions out of 287 were non-interactive regions. These regions, which lack potential access to external knowledge by means of formal and informal linkages, are mainly those belonging to the New Entrant countries and some specific regions in southern European countries (all of Portugal and Greece, most of Spain except the central area and the south of Italy).

Knowledge Networking Regions. Networking regions are concentrated in the centre of Europe as well as in the Scandinavian countries. These regions are physically located close to high performing regions, so they are potentially in an advantageous position to benefit from informal 
knowledge diffusion mechanisms. However, they also act as knowledge hubs that are formally connected to external knowledge pools. As we can see, this sub-sample consists of 118 regions out of 287, which are mostly located in Germany, the Netherlands, Belgium, Denmark, southern Sweden, southern Finland, Switzerland, northern Italy, south-east England and part of France. Therefore, apart from 3 northern Italian regions, no other region in Southern or Eastern Europe appears on the list. This supports a clear core-periphery pattern in the geographical distribution of the regions that in one way or another rely on external sources of knowledge for the development of innovation. Therefore, broadly speaking, knowledge networking regions are those that are better positioned to benefit more from spatial knowledge diffusion, through different regimes and at different spatial scales, and from the construction of the European Research Area.

[Insert Figure 3 about here]

\subsection{Robustness analysis}

Here we list a number of robustness checks that we have performed for the calculation of the two sub-indicators presented so far. The results (the number and type of regions in each category) do not vary to a large extent. Consequently, most of the results are not presented here to save space. However, they can be provided by the authors on request. A few of the maps resulting from these checks are shown in Figure 4 below.

Firstly, we recalculated the informal linkages composite indicator using different weight matrices. Concretely, less complex matrices were used, such as a first-order contiguity matrix (Figure 4.1), an inverse distance matrix, and a squared inverse distance matrix (Figure 4.2). Any significant variation must be set apart (as expected, the first-order contiguity weight matrix slightly shifted the typological classification of some of the regions, which reflects the heterogeneous size of European NUTS2 regions).

Secondly, we recalculated the formal linkages indicator by subtracting all the linkages made with regions contiguous to the focal region (Figure 4.3), regions whose centroid lies within $300 \mathrm{~km}$ of the centroid of the focal region, regions belonging to the same NUTS1 as the focal region, and regions belonging to the same country as the focal region (Figure 4.4). Even though a few changes were observed, the general picture remains the same.

[Insert Figure 4 about here] 


\section{Concluding remarks and policy implications}

In the previous sections, we described a detailed method to construct a composite indicator and two sub-indices that examine the ways in which actors in regions may access external-to-theregion pools of different and complementary knowledge. In motivating our approach, we extensively surveyed an instrumental list of theoretical and empirical studies across different disciplines and sub-disciplines. These studies have more or less dealt with the mechanisms through which knowledge diffuses, especially across space and between different locations. Based on our method, we also provided a typology of regions that captures their diversity in terms of their degree of openness to external sources of knowledge. Finally, the NUTS2 regions of 31 European countries were used to apply our novel approach and derive preliminary conclusions and policy implications from the results.

In spite of increasing evidence of the role of knowledge diffusion across different geographical areas and the importance of this phenomenon for regional innovation, our review showed that mainstream research and policymakers barely consider this issue when they assess the innovative performance of cities, regions or countries. We believe that connections to external sources of knowledge are as important for regions as their scientific and technological base, and policies that specifically focus on this issue might be required. For years, regional policy programs have aimed to strengthen the local cluster knowledge base and its social pre-conditions for innovation (Rodríguez-Pose and Crescenzi, 2008). Here, we call into question this narrow approach and propose that the external dimension of regions is also relevant. Since this dimension has been quietly overlooked so far, policymakers lack a critical pillar for the development of regional innovation systems. However, as stressed in Bathelt et al. (2004), the 'local buzz' basically takes care of itself, whilst external linkages specifically require institutional and infrastructure support. The present inquiry was an attempt to open up a future research agenda within the literature to improve our understanding of the external dimension of regional innovation systems and consequently develop a battery of policies on this issue.

Next, our empirical approach provided a typology of four distinct types of regions according to their degree of openness to external sources of knowledge, as well as their specialization in the different ways in which actors in these regions may access external knowledge, that is, formal and informal linkages. This diversity of regions suggests that specific policies should be applied to each type of region, not only according to their innovative performance and social pre-conditions, but also according to the ways in which they connect with outsiders. This typology also translates into a ranking, which could serve as a guideline for regions to identify other areas with similar 
development conditions that have achieved a better rank and whose best practices could serve as a benchmark for implementing similar policies elsewhere.

Finally, our study also provides elements that could help firms' localization policies. As stressed in Gertler and Levitte (2005), firms' location decisions are influenced by the endogenous characteristics of regions and by opportunities to benefit from linkages worldwide, through which they can access manifold knowledge pools. 


\section{References}

Acs, Z.J., Audretsch, D.B. and Feldman, M.P. (1994) R\&D spillovers and recipient firm size. Review of Economics and Statistics 76(2): 363-367.

Allen, T.J. (1977) Managing the flow of technology: technology transfer and the dissemination of technological information within the R\&D organization. Cambridge, Massachusetts: MIT Press.

Almeida, P., Kogut, B. (1997) The exploration of technological diversity and the geographic localization of innovation. Small Business Economics 9(1): 21-31.

Almeida, P. and Kogut, B. (1999) Localisation of knowledge and the mobility of engineers in regional networks. Management Science 45(7): 905-917.

Anselin, L., Varga, A. and Acs, Z. (1997) Local Geographic Spillovers between University Research and High Technology Innovations. Journal of Urban Economics 42(3): 422-448.

Arthur, W.B. (1989) Competing Technologies, Increasing Returns, and Lock-in by Historical Events. Economic Journal 99: 116-131.

Arrow, K.J. (1962) The Economic Implications of Learning by Doing. Review of Economic Studies 29(3): 155-173.

Asheim, B.T. and Isaksen, A. (2002) Regional innovation systems: The integration of local 'sticky' and global 'ubiquitous' knowledge. Journal of Technology Transfer 27(1): 77-86.

Audretsch, D.B. and Feldman, M.P. (1996) R\&D Spillovers and the geography of innovation and production. The American Economic Review 86(3): 630-640.

Audretsch, D.B. and Feldman, M.P. (2004) Knowledge Spillovers and the Geography of Innovation, in V. Henderson and J. Thisse (Eds) Handbook of Urban and regional Economics, Volume 4.

Autant-Bernard, C. and LeSage, J.P. (2011): Quantifying knowledge spillovers using spatial econometric models. Journal of Regional Science 51(3): 471-496.

Autant-Bernard, C. and Massard, N. (2009) Underlying mechanisms of knowledge diffusion. IAREG Working Paper 4.7

Autio, E. (1998) Evaluation of RTD in regional system of innovation. European Planning Studies 6(2): 131-140.

Bahlmann, M.D., Huysman, M.H., Elfring, T. and Groenewegen, P. (2008) Global pipelines or global buzz? A micro-level approach towards the knowledge-based view of clusters. VU University Amsterdam, Serie Research Memoranda 0002.

Bathelt, H., Malberg, A. and Maskell, P. (2004) Clusters and knowledge: local buzz, global pipelines and the process of knowledge creation. Progress in Human Geography 28(1): 31-56.

Becattini, G. (1979) Dal 'settore' industriale al 'distretto' industriale. Alcune considerazioni sull'unità d'indagine dell'economia industriale. Rivista di economia e politica industriale 5(1): 7-21. 
Belussi, F., Sammarra, A., Sedita, S.R. (2010) Learning at the boundaries in an "Open Regional Innovation System": A focus on firms' innovation strategies in the Emilia Romagna life science industry. Research Policy 39(6): 710-721.

Bergman, E.M. and Maier, G. (2009) Network central: regional positioning for innovative advantage. The Annals of regional Science 43(3): 615-644.

Bode, E. (2004) The spatial pattern of localized R\&D spillovers: an empirical investigation for Germany. Journal of Economic Geography 4(1): 43-64.

Boschma, R. (2005) Proximity and Innovation: A Critical Assessment. Regional Studies 39(1): 6174.

Boschma, R., Eriksson, R. and Lindgren, U. (2009) How does labour mobility affect the performance of plants? The importance of relatedness and geographical proximity. Journal of Economic Geography 9(2): 169-190.

Boschma, R. and Frenken, K. (2010) The spatial evolution of innovation networks. A proximity perspective, in: R. Boschma and R. Martin (eds.) The Handbook of Evolutionary Economic Geography, Cheltenham: Edward Elgar, pp. 120-135.

Boschma, R.A. and lammarino, S. (2009) Related Variety, Trade Linkages and Regional Growth. Economic Geography 85(3): 289-311.

Bottazzi, L. and Peri, G. (2003) Innovation and spillovers in regions: Evidence from European patent data. European Economic Review 47(4): 687-710.

Breschi, S. and Lissoni, F. (2001a) Localised knowledge spillovers vs. innovative millieux: Knowledge "tacitness" reconsidered. Papers in Regional Science 80(3): 255-273.

Breschi, S. and Lissoni, F. (2001b) Knowledge spillovers and local innovation systems: A critical survey, Industrial and Corporate Change 10(4): 975-1005.

Breschi, S. and Lissoni, F. (2004) Knowledge networks from patent data: methodological issues and research targets, in Moed H., Glänzel W. and Schmoch U. (Eds) Handbook of Quantitative Science and Technology Research: The Use of Publication and Patent Statistics in Studies of S\&T Systems, pp. 613-643. Springer Verlag, Berlin.

Breschi, S. and Lissoni, F. (2009) Mobility of skilled workers and co-invention networks: an anatomy of localized knowledge flows. Journal of Economic Geography 9(4): 439-468.

Breschi, S., Lenzi, C., Lissoni, F. and Vezzulli, A. (2010) The geography of knowledge spillovers: the role of inventors' mobility across firms and in space, in: R. Boschma and R. Martin (eds.) The Handbook of Evolutionary Economic Geography, Cheltenham: Edward Elgar, pp. 353369.

Burt, R.S. (1992) Structural Holes: The Social Structure of Competition. Cambridge, Massachusetts: Harvard University Press.

Camagni, R. (1991) Innovation networks: spatial perspectives. Belhaven-Pinter: London 
Camagni, R. and Capello, R. (2009) Knowledge-base economy and knowledge creation: The role of space, in Fratesi, U. and Senn, L. (Eds.) Growth and Innovation of Competitive Regions: The Role of Internal and External Connections, pp. 145-166. Springer-Verlag, Berlin.

Capello, R. (1999) Spatial Transfer of Knowledge in High-technology Milieux: Learning vs. Collective Learning Processes. Regional Studies 33(4): 353-365.

Carrincazeaux, C., Lung, Y. and Vicente, J. (2008) The Scientific History of the French School of Proximity: interaction- and Institution-based Approaches to Regional Innovation Systems. European Planning Studies 16(5): 617-628.

Cassiman, B. and Veugelers, R. (2006) In Search of Complementarity in Innovation Strategy: Internal R\&D and External Knowledge Acquisition. Management Science 52(1): 68-82.

Coe, N.M. and Bunnell, T. (2003) 'Spatializing' knowledge communities: towards a conceptualisation of transnational innovation networks'. Global Networks 3(4): 437-456.

Cohen, W.M. and Levinthal, D.A. (1990) Absorptive capacity: a new perspective on learning and innovation. Administrative Science Quarterly 35(1): 128-152.

Cooke, P., Boekholt, P. and Tödtling, F. (2000) The Governance of Innovation in Europe. London: Pinter.

Cowan, R. and Jonard, N. (2004) Network structure and the diffusion of knowledge. Journal of Economic Dynamics and Control 28(8): 1557-1575.

David, P.A. (1985) Clio and the Economics of QWERTY. American Economic Review 75(2): 332337.

D'Este, P. and lammarino, S. (2010) The spatial profile of university-business research partnerships. Papers in Regional Science 89(2): 335-350.

Dosi, G. (1988) Sources, procedures and microeconomic effects of innovation. Journal of Economic Literature 26(3): 1120-1171.

European Commission (2007) Green Paper. The European research area: new perspectives. $\operatorname{COM}(2007) 161$.

European Commission (2010) A vision for strengthening world-class research infrastructures in the ERA. Report of the Expert Group on Research Infrastructures.

European Commission (2011) Regional Innovation Monitor. Innovation Patterns and Innovation Policy in European Regions - Trends, Challenges and Perspectives. Project No. 0932. Enterprise and Industry Directorate-General

Feldman, M.P. (1994) Knowledge complementarity and innovation. Small Business Economics 6(5): 363-372.

Feldman, M.P. and Audretsch, D. (1999) Innovation in cities:: Science-based diversity, specialization and localized competition. European Economic Review 43(2): 409-429. 
Fratesi, U. and Senn, L. (2009) "Regional Growth, Connections and Economic Modelling: An Introduction", in Fratesi, U. and Senn, L. (Eds.) Growth and Innovation of Competitive Regions: The Role of Internal and External Connections, pp. 3-28. Springer-Verlag, Berlin.

Gertler, M.S. (1995) 'Being there': proximity, organization, and culture in the development and adoption of advanced manufacturing technologies. Economic Geography 71(1): 1-26.

Gertler, M.S. (2003) Tacit knowledge and the economic geography of context, or the indefinable tacitness of being (there). Journal of Economic Geography 3(1): 75-99.

Gertler, M.S. and Levite, Y.M. (2005) Local nodes in global networks: the geography of knowledge flows in biotechnology innovation. Industry and Innovation 12(4): 487-507.

Gittelman, M. (2007) Does geography matter for science-based firms? Epistemic communities and the geography of research and patenting in biotechnology. Organization Science 18(4): 724741.

Giuliani, E. and Bell, M. (2005) The micro-determinants of meso-level learning and innovation: evidence from a Chilean wine cluster. Research Policy 34(1): 47-68.

Glaeser, E., Laibson, D. and Sacerdote, B. (2002) An economic approach to social capital. Economic Journal 112(483): 437-458.

Glückler, J. (2007) Economic geography and the evolution of networks. Journal of Economic Geography 7(5): 619-634.

Gomes-Casseres, B., Hagedoorn, J., and Jaffe, A.B. (2006) Do alliances promote knowledge flows? Journal of Financial Economics 80(1), 5-33.

Grabher, G. (1993) The weakness of strong ties: the lock-in of regional development in the Ruhr area. In G. Grabher (ed.) The Embedded Firm, London: Routledge, pp. 255-277.

Granovetter, M.S. (1973) The Strength of Weak Ties The American Journal of Sociology 78(6): 1360-1380.

Griliches, Z. (1991) Patent Statistics as Economic Indicators: A Survey. NBER Working Papers 3301

Grossman, G.M. and Helpman, E. (1991) Innovation and Growth in the Global Economy. Cambridge, Massachusetts: MIT Press.

Hagerstrand, T. (1965) Aspects of the Spatial Structure of Social Communication and the Diffusion of Information. Papers of the Regional Science Association 16(1): 27-42.

lammarino, S. and McCann, P. (2006) The structure and evolution of industrial clusters: Transactions, technology and knowledge spillovers. Research Policy 35(7): 1018-1036.

INSEAD (2011) Global Innovation Index 2011, INSEAD

Jaffe, A.B. (1986) Technological Opportunity and Spillovers of R\&D: Evidence from Firms' Patents, Profits, and Market Value. American Economic Review 76(5): 984-1001. 
Jaffe, A.B. (1989) Real effects of academic research, American Economic Review 79(5): 957-970.

Jaffe, A.B., Trajtenberg, M. and Henderson, R. (1993) Geographic localisation of knowledge spillovers as evidenced by patent citations. Quarterly Journal of Economics 108(3): 577-598.

Kroll, H. (2009) Spillovers and proximity in perspective: A network approach to improving the operationalisation of proximity. Working Papers Firms and Regions No. R2/2009, Fraunhofer ISI.

Krugman, P. (1991a): Geography and Trade. Cambridge, Massachusetts: MIT Press.

Krugman, P. (1991b) Increasing returns and economic geography. Journal of Political Economy 99(3): 483-499.

Lambooy, J.G. and Boschma, R.A. (2001) Evolutionary economics and regional policy. Annals of Regional Science 35(1) 113-133.

Laudel, G. (2003) Studying the Brain Drain: Can Bibliometric Methods Help? Scientometrics 57(2): 215-237.

Lenzi, C. (2010) Technology mobility and job mobility: On the use of patent data for inventors' career analysis", unpublished manuscript.

Lorenz, E. (1996) Collective learning processes and the regional labour market, unpublished research note, European Network on Networks, Collective Learning and RTD in RegionallyClustered High-Technology SMEs

Lucas, R. E. (1988) On the mechanics of economic development. Journal of Monetary Economics 22(1): 3-42.

Maggioni, M.A., Nosvelli, M. and Uberti, T.E. (2007) Space versus networks in the geography of innovation: A European analysis. Papers in Regional Science 86(3): 471-493.

Maggioni, M.A. and Uberti, T.E. (2011) Networks and geography in the economics of knowledge flows. Quality and Quantity 45(5): 1031-1051.

Marsan, G.A. and Maguire, K. (2011) Categorisation of OECD regions using innovation-related variables. Organisation for Economic Co-operation and Development (OECD) regional development working paper No. 2011/03.

Maskell, P., Bathelt, H. and Malmberg, A. (2006) Building global knowledge pipelines: The role of temporary clusters. European Planning Studies 14(8): 997-1013.

March, J.G. (1991) Organizational Consultants and Organizational Research. Journal of Applied Communication Research 19(1-2): 20-31.

Martin, P. and Ottaviano, G. (1999) Growing locations: Industry location in a model of endogenous growth. European Economic Review 43(2): 281-302.

Martin R. and Sunley, P. (2006) Path dependence and regional economic evolution. Journal of Economic Geography 6(4): 395-437. 
Marshall, A. (1920) Principles of Economics. Londres, Macmillan.

Miguélez, E. and Gómez-Miguélez, I.G. (2011) Singling out individual inventors from patent data, IREA Working Paper 2011/05.

Moreno, R., Paci, R. and Usai, S. (2005) Spatial spillovers and innovation activity in European regions. Environment and Planning A 37(10): 1793-1812.

Moretti, E. (2004) Human capital externalities in cities. In: V. Henderson and J. Thisse (eds) Handbook of Urban and Regional Economics, vol. 4.

Morrison, A., Rabellotti, R. and Zirulia, F.L. (2011) When do global pipelines enhance knowledge diffusion in clusters?. Papers in Evolutionary Economic Geography (PEEG) 1105, Utrecht University.

Navarro, M., Gibaja, J.J., Bilbao-Osorio, B. and Aguado, R. (2009) Patterns of innovation in EU-25 regions: a typology and policy recommendations. Environment and Planning C: Government and Policy 27(5): 815-840.

Organizational Consultants and Organizational Research (2009) OECD regions at a glance 2009. Paris: Organizational Consultants and Organizational Research. DOI: 10.1787/reg_glance2011-en

Owen-Smith, J. and Powell, W.W. (2004) Knowledge networks as channels and conduits: the effects of spillovers in the Boston biotechnology community. Organization Science 15(1): 5- 21.

Parent, O. and LeSage, J.P. (2008) Using the variance structure of the conditional autoregressive spatial specification to model knowledge spillovers. Journal of Applied Econometrics 23(2): 235-256.

Peri, G. (2005) Determinants of Knowledge Flows and Their Effect on Innovation. The Review of Economics and Statistics 87(2): 308-322.

Ponds, R., Van Oort, F.G. and Frenken, K. (2010) Innovation, spillovers and university-industry collaboration: An extended knowledge production function approach. Journal of Economic Geography 10 (2): 231-255.

Porter, M.E. (1990) The Competitive Advantage of Nations, London: Macmillan.

Rauch, J.E. (1993) Productivity gains from geographic concentration of human capital: Evidence from the cities. Journal of Urban Economics 34 (3): 380-400.

Regional Innovation Scoreboard (2009) Regional Innovation Scoreboard, Pro Inno Europe. Inno Metrics.

Rodríguez-Pose, A. and Crescenzi, R. (2008) Reseacrh and Development, Spillovers, Innovation Systems, and the Genesis of Regional Growth in Europe. Regional Studies 42(1): 51-67.

Romer P.M. (1986) Increasing Returns and Long-run Growth. Journal of Political Economy 94(5): 1002-1037.

Romer P.M. (1990) Endogenous Technological Change. Journal of Political Economy 98(5): 71102. 
Rosenkopf, L. and Almeida, P. (2003) Overcoming local search through alliances and mobility. Management Science 49(6): 751-766.

Rychen, F. and Zimmermann, J.B. (2008) Clusters in the Global Knowledge-based Economy: Knowledge Gatekeepers and Temporary Proximity. Regional Studies 42(6): 767-776.

Simonen, J. \& McCann, P. (2008) Firm innovation: The influence of R\&D cooperation and the geography of human capital inputs. Journal of Urban Economics 64(1): 146-154.

Singh, J. (2005) Collaborative Networks as Determinants of Knowledge Diffusion Patterns. Management Science 51(5): 756-770.

Singh, J. and Agrawal, A.K. (2011) Recruiting for Ideas: How Firms Exploit the Prior Inventions of New Hires. Management Science 57(1): 129-150.

Steinmueller, W.E. (2000) Will New Information and Communication Technologies Improve the 'Codification' of Knowledge? Industrial and Corporate Change 9(2): 361-376.

Storper, M. (1997) The regional world. New York and London: The Guilford Press.

Storper, M. and Venables, A. (2004) Buzz: face-to-face contact and the urban economy. Journal of Economic Geography 4(4): 351-370.

Ter Wal, A.L.J. and Boschma, R. (2009) Applying social network analysis in economic geography: framing some key analytic issues. The Annals of Regional Science 43(3): 739-756.

Todtling, F. and Trippl, M. (2005) One size fits all?: Towards a differentiated regional innovation policy approach. Research Policy 34(8): 1203-1219.

Todtling F., Lehner P. and Trippl, M. (2006) Innovation in Knowledge Intensive Industries: The Nature and Geography of Knowledge Links European Planning Studies 14(8): 1035-1058.

Torre A. (2008) On the Role Played by Temporary Geographical Proximity in Knowledge Transmission. Regional Studies 42(6): 869-889.

Trippl, M. and Maier, G. (2010) Knowledge spillover agents and regional development. Papers in Regional Science 89(2): 229-233.

Trippl, M., Tödtling, F. and Lengauer, L. (2009) Knowledge Sourcing Beyond Buzz and Pipelines: Evidence from the Vienna Software Sector. Economic Geography 85(4): 443-462.

Uzzi, B. (1996) The sources and consequences of embeddedness for the economic performance of organizations. American Sociological Review 61(4): 674-698.

Vang, J. and Chaminade, C. (2007) Cultural Clusters, Global-Local Linkages and Spillovers: Theoretical and Empirical Insights from an Exploratory Study of Toronto's Film Cluster. Industry \& Innovation 14(4): 401-420.

Verspagen, B. and Schoenmakers, W. (2004) The spatial dimension of patenting by multinational firms in Europe. Journal of Economic Geography 4(1): 23-42.

Zucker, L.G., Darby, M.R. and Armstrong, J. (1998) Geographically Localized Knowledge: Spillovers or Markets? Economic Inquiry 36(1): 65-86. 


\section{ANNEX}

Figure 1. A typology of regions according to the type of linkages to external sources of knowledge

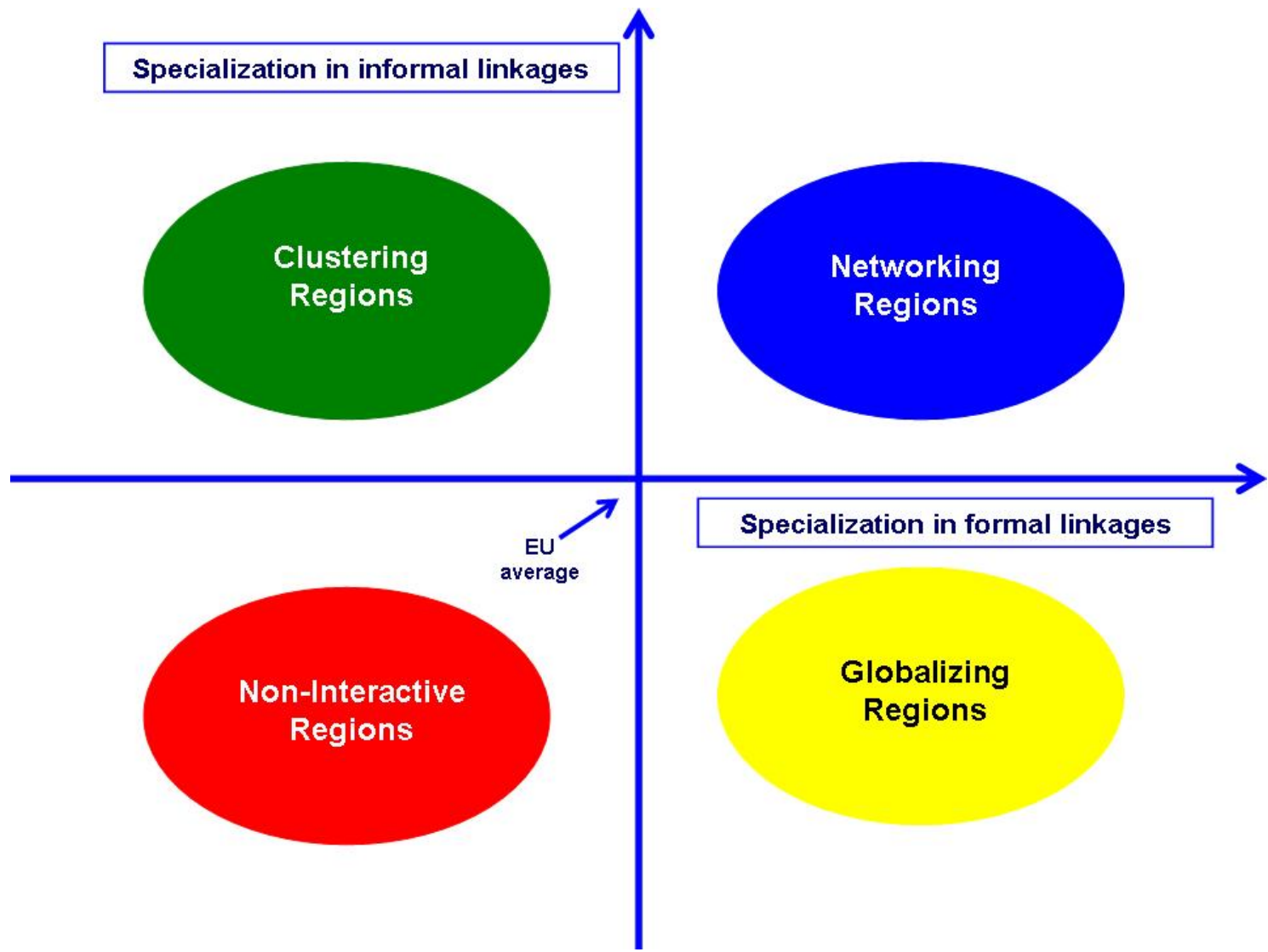


Table 1. Description of the variables used for the synthetic indicators

\begin{tabular}{|c|c|c|c|c|}
\hline Variable & Description & Sources & $\begin{array}{c}\text { Years } \\
\text { considered }\end{array}$ & Weight \\
\hline \multicolumn{5}{|c|}{ VARIABLES USED FOR THE CONSTRUCTION OF THE SYNTHETIC INDICATOR ON SPATIAL LINKAGES } \\
\hline $\begin{array}{l}\text { R\&D exp. per capita } \\
\text { in the neighbouring } \\
\text { regions }\end{array}$ & $\begin{array}{l}\text { Average value of the millions of Euros } \\
\text { spent on RD activities over population in } \\
\text { the closest neighbouring regions: } \\
\text { wij=exp(-0.01-dij), cut-off } 300 \mathrm{~km}\end{array}$ & $\begin{array}{l}\text { Compiled by CRENoS } \\
\text { using Eurostat, ISTAT } \\
\text { and Institut National } \\
\text { de la Statistique et des } \\
\text { Études Économiques }\end{array}$ & 2006-2007 & $1 / 3$ \\
\hline $\begin{array}{l}\text { Patent activity per } \\
\text { capita in the } \\
\text { neighbouring regions }\end{array}$ & $\begin{array}{l}\text { Average number of patents released over } \\
\text { population in the closest neighbouring } \\
\text { regions: wij=exp(-0.01.dij), cut-off } 300 \mathrm{~km}\end{array}$ & $\begin{array}{l}\text { Compiled by CRENoS } \\
\text { using the OECD } \\
\text { REGPAT database } \\
\end{array}$ & 2005-2006 & $1 / 3$ \\
\hline $\begin{array}{l}\text { Human capital in the } \\
\text { neighbouring regions }\end{array}$ & $\begin{array}{l}\text { Percentage of population aged } 15 \text { and } \\
\text { over with tertiary education in the closest } \\
\text { neighbours: wij=exp(-0.01·dij), cut-off } 300 \\
\text { km }\end{array}$ & $\begin{array}{l}\text { Compiled by CRENoS } \\
\text { using Eurostat }\end{array}$ & 2005-2007 & $1 / 3$ \\
\hline \multicolumn{5}{|c|}{ VARIABLES USED FOR THE CONSTRUCTION OF THE SYNTHETIC INDICATOR ON A-SPATIAL LINKAGES } \\
\hline Co-patents per capita & $\begin{array}{l}\text { Number of patent co-authored with } \\
\text { inventors from outside the region over } \\
\text { population }\end{array}$ & $\begin{array}{l}\text { Compiled by AQR } \\
\text { using the OECD } \\
\text { REGPAT database }\end{array}$ & $2002-2004$ & $1 / 3$ \\
\hline $\begin{array}{l}\text { Inflows of inventors } \\
\text { per capita }\end{array}$ & $\begin{array}{l}\text { Number of inflows of inventors coming } \\
\text { from other regions over population }\end{array}$ & $\begin{array}{l}\text { Compiled by AQR } \\
\text { using the OECD } \\
\text { REGPAT database }\end{array}$ & 2002-2004 & $1 / 3$ \\
\hline $\begin{array}{l}\text { Cross-regional } \\
\text { citations per capita }\end{array}$ & $\begin{array}{l}\text { Number of citations made to patents from } \\
\text { other regions over population }\end{array}$ & $\begin{array}{l}\text { Compiled by CRENoS } \\
\text { using the OECD } \\
\text { REGPAT and citations } \\
\text { database }\end{array}$ & 2002-2004 & $1 / 3$ \\
\hline
\end{tabular}


Figure 2. Scatter plot of European regions. Formal linkages vs. informal linkages

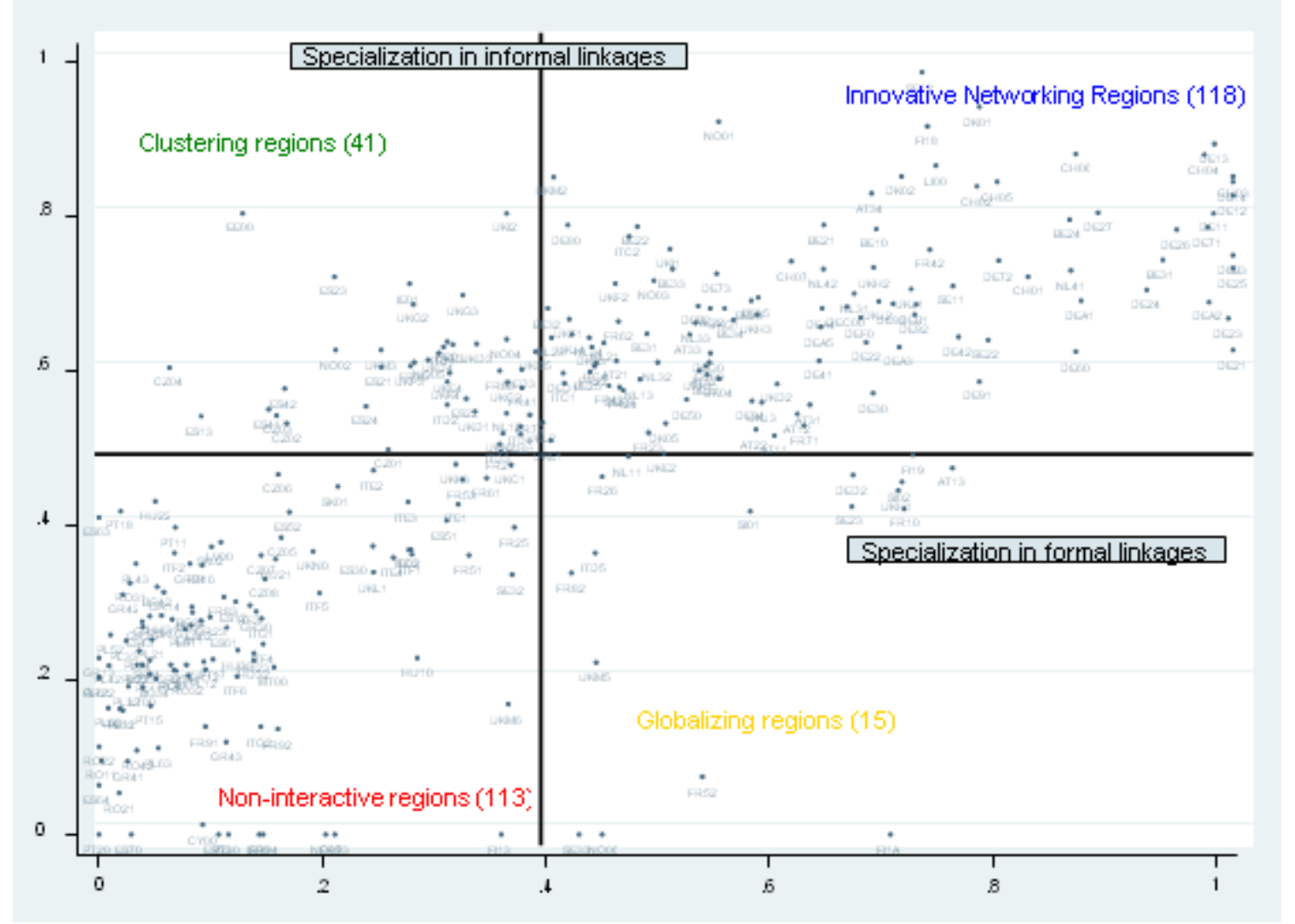


Figure 3. Typology of regions depicted on a map

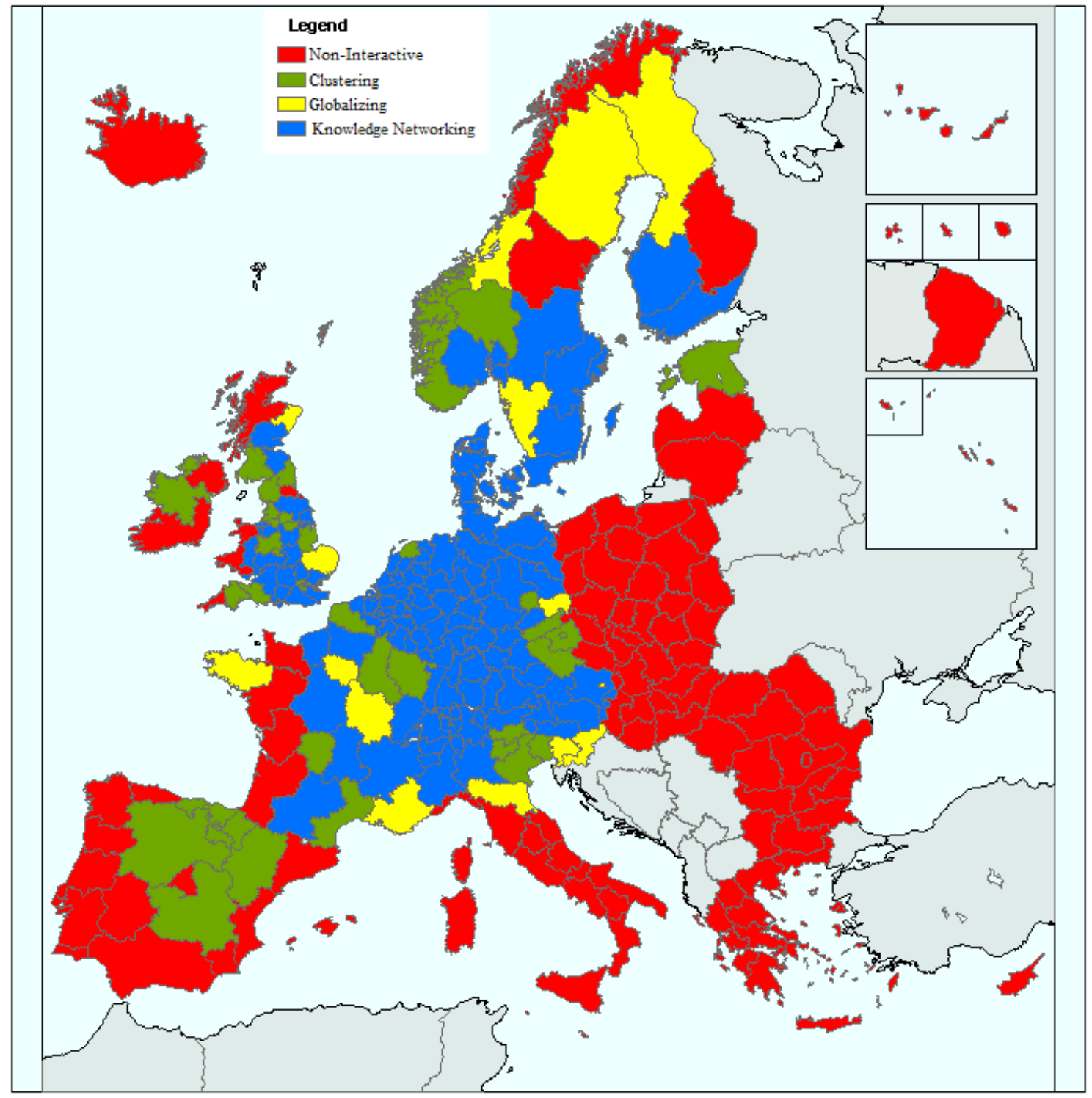


Figure 4. Typology of regions depicted on a map. Robustness analysis

Figure 4.1. First order contiguity weight matrix

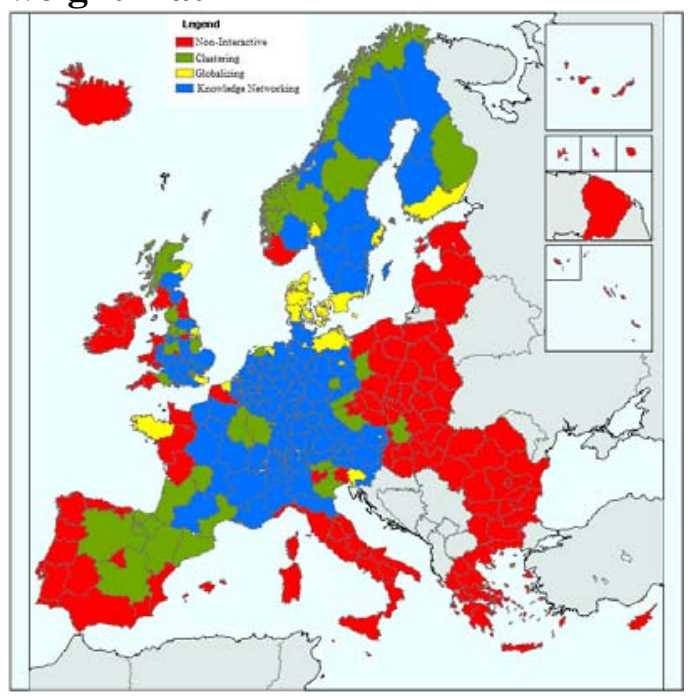

Figure 4.3. Formal linkages between contiguous regions excluded

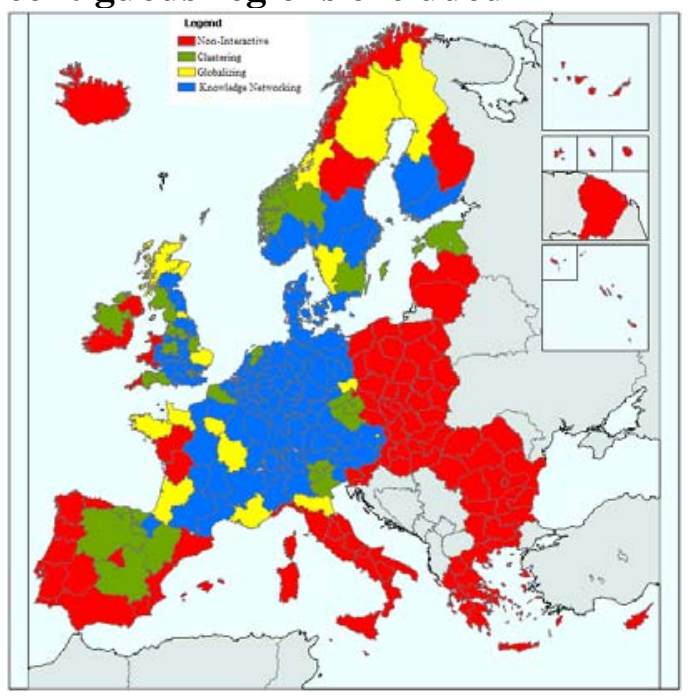

Figure 4.2. Inverse of the squared distance weight matrix

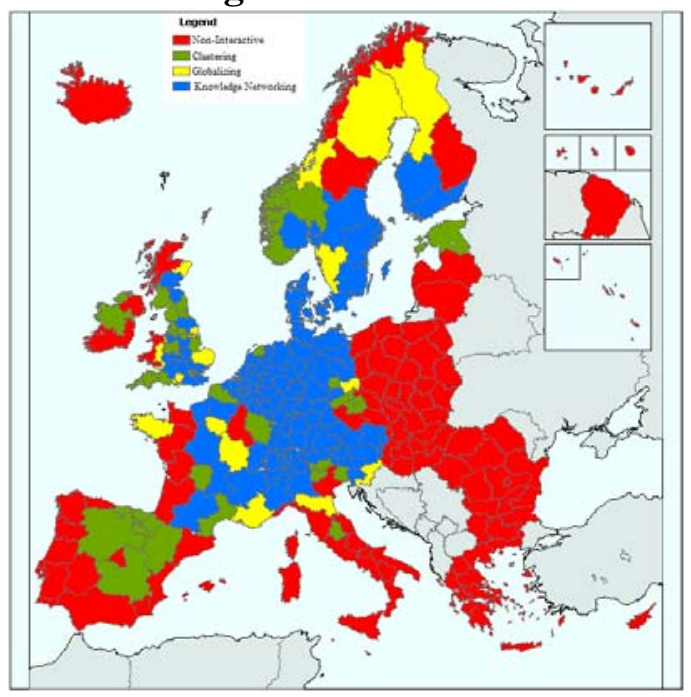

Figure 4.4. Formal linkages within countries excluded

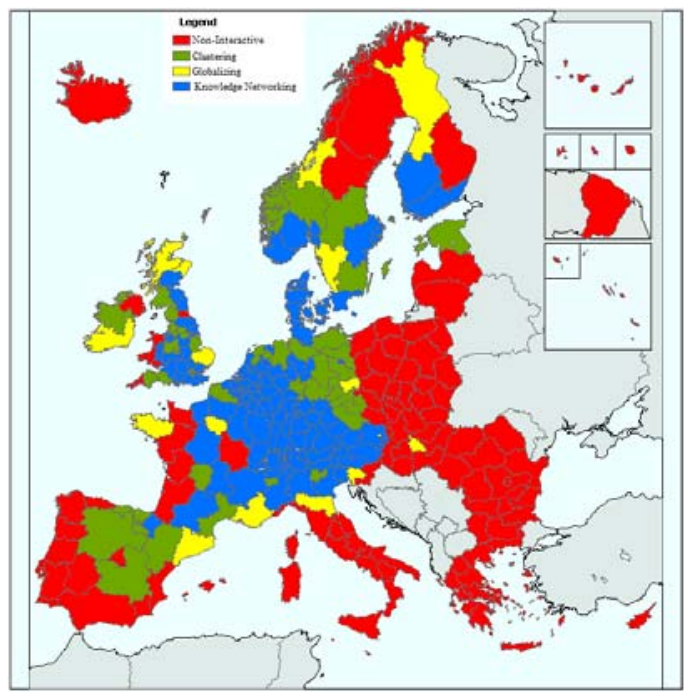


Appendix. List of countries (and number of regions in each one):

Austria, AT (9), Belgium, BE (11), Bulgaria, BG (6), Switzerland, CH (1), Cyprus, CY (1), Czech Republic, CZ (8), Germany, DE (39), Denmark, DK (5), Estonia, EE (1), Spain, ES (19), Finland, FI (5), France, FR (26), Greece, GR (13), Hungary, HU (7), Ireland, IE (2), Iceland, IS (1), Liechtenstein, LI (1), Italy, IT (20), Lithuania, LT (1), Luxemburg, LU (1), Latvia, LV (1), Malta, MT (1), the Netherlands, NL (12), Norway, NO (7), Poland, PL (16), Portugal, PT (7), Romania, RO (8), Sweden, SE (8), Slovenia, SI (2), Slovakia, SK (4), United Kingdom, UK (12). 
Llista Document de Treball

List Working Paper

WP 2011/21 “A relational approach to the geography of innovation: a typology of regions” Moreno, R. and Miguélez, E.

WP 2011/20 “Does Rigidity of Prices Hide Collusion?” Jiménez, J.L and Perdiguero, J.

WP 2011/19 "Factors affecting hospital admission and recovery stay duration of in-patient motor victims in Spain” Santolino, M.; Bolancé, C. and Alcañiz, M.

WP 2011/18 "Why do municipalities cooperate to provide local public services? An empirical analysis” Bel, G.; Fageda, X. and Mur, M.

WP 2011/17 "The "farthest" need the best. Human capital composition and development-specific economic growth” Manca, F.

WP 2011/16 “Causality and contagion in peripheral EMU public debt markets: a dynamic approach” Gómez-Puig, M. and Sosvilla-Rivero, S.

WP 2011/15 “The influence of decision-maker effort and case complexity on appealed rulings subject to multicategorical selection” Santolino, M. and Söderberg, M.

WP 2011/14 “Agglomeration, Inequality and Economic Growth: Cross-section and panel data analysis” Castells, D.

WP 2011/13 “A correlation sensitivity analysis of non-life underwriting risk in solvency capital requirement estimation” Bermúdez, L.; Ferri, A. and Guillén, M.

WP 2011/12 “Assessing agglomeration economies in a spatial framework with endogenous regressors” Artis, M.J.; Miguélez, E. and Moreno, R.

WP 2011/11 “Privatization, cooperation and costs of solid waste services in small towns” Bel, G; Fageda, X. and Mur, M.

WP 2011/10 "Privatization and PPPS in transportation infrastructure: Network effects of increasing user fees" Albalate, D. and Bel, G.

WP 2011/09 "Debating as a classroom tool for adapting learning outcomes to the European higher education area" Jiménez, J.L.; Perdiguero, J. and Suárez, A.

WP 2011/08 “Influence of the claimant’s behavioural features on motor compensation outcomes” Ayuso, M; Bermúdez L. and Santolino, M.

WP 2011/07 “Geography of talent and regional differences in Spain” Karahasan, B.C. and Kerimoglu E.

WP 2011/06 “How Important to a City Are Tourists and Daytrippers? The Economic Impact of Tourism on The City of Barcelona” Murillo, J; Vayá, E; Romaní, J. and Suriñach, J.

WP 2011/05 “Singling out individual inventors from patent data” Miguélez,E. and Gómez-Miguélez, I.

WP 2011/04 “¿La sobreeducación de los padres afecta al rendimiento académico de sus hijos?” Nieto, S; Ramos, R.

WP 2011/03 “The Transatlantic Productivity Gap: Is R\&D the Main Culprit?” Ortega-Argilés, R.; Piva, M.; and Vivarelli, M.

WP 2011/02 “The Spatial Distribution of Human Capital: Can It Really Be Explained by Regional Differences in Market Access?” Karahasan, B.C. and López-Bazo, E

WP 2011/01 "If you want me to stay, pay”. Claeys, P and Martire, F

WP 2010/16 "Infrastructure and nation building: The regulation and financing of network transportation infrastructures in Spain (1720-2010)”Bel,G 
WP 2010/15 "Fiscal policy and economic stability: does PIGS stand for Procyclicality In Government Spending?” Maravalle, A ; Claeys, P.

WP 2010/14 “Economic and social convergence in Colombia” Royuela, V; Adolfo García, G.

WP 2010/13 “Symmetric or asymmetric gasoline prices? A meta-analysis approach” Perdiguero, J.

WP 2010/12 “Ownership, Incentives and Hospitals” Fageda,X and Fiz, E.

WP 2010/11 “Prediction of the economic cost of individual long-term care in the Spanish population” Bolancé, C; Alemany, R ; and Guillén M

WP 2010/10 “On the Dynamics of Exports and FDI: The Spanish Internationalization Process” Martínez-Martín, J.

WP 2010/09 “Urban transport governance reform in Barcelona” Albalate, D ; Bel, G and Calzada, J.

WP 2010/08 “Cómo (no) adaptar una asignatura al EEES: Lecciones desde la experiencia comparada en España” Florido C. ; Jiménez JL. and Perdiguero J.

WP 2010/07 "Price rivalry in airline markets: A study of a successful strategy of a network carrier against a lowcost carrier” Fageda, X ; Jiménez J.L. ; Perdiguero , J.

WP 2010/06 "La reforma de la contratación en el mercado de trabajo: entre la flexibilidad y la seguridad” Royuela V. and Manuel Sanchis M.

WP 2010/05 “Discrete distributions when modeling the disability severity score of motor victims” Boucher, J and Santolino, M

WP 2010/04 "Does privatization spur regulation? Evidence from the regulatory reform of European airports . Bel, G. and Fageda, X.”

WP 2010/03 “High-Speed Rail: Lessons for Policy Makers from Experiences Abroad”. Albalate, D ; and Bel, G.”

WP 2010/02 “Speed limit laws in America: Economics, politics and geography”. Albalate, D ; and Bel, G.”

WP 2010/01 “Research Networks and Inventors’ Mobility as Drivers of Innovation: Evidence from Europe” Miguélez, E. ; Moreno, R.”

WP 2009/26 Social Preferences and Transport Policy: The case of US speed limits” Albalate, D.

WP 2009/25 Human Capital Spillovers Productivity and Regional Convergence in Spain” , Ramos, R ; Artis, M.; Suriñach, J.

WP 2009/24 “Human Capital and Regional Wage Gaps”,López-Bazo,E. Motellón E.

WP 2009/23 “Is Private Production of Public Services Cheaper than Public Production? A meta-regression analysis of solid waste and water services” Bel, G.; Fageda, X.; Warner. M.E.

WP 2009/22 “Institutional Determinants of Military Spending” Bel, G., Elias-Moreno, F.

WP 2009/21 “Fiscal Regime Shifts in Portugal” Afonso, A., Claeys, P., Sousa, R.M.

WP 2009/20 "Health care utilization among immigrants and native-born populations in 11 European countries. Results from the Survey of Health, Ageing and Retirement in Europe” Solé-Auró, A., Guillén, M., Crimmins, E.M.

WP 2009/19 "La efectividad de las políticas activas de mercado de trabajo para luchar contra el paro. La experiencia de Cataluña” Ramos, R., Suriñach, J., Artís, M.

WP 2009/18 “Is the Wage Curve Formal or Informal? Evidence for Colombia” Ramos, R., Duque, J.C., Suriñach, J. 
WP 2009/17 “General Equilibrium Long-Run Determinants for Spanish FDI: A Spatial Panel Data Approach” Martínez-Martín, J.

WP 2009/16 “Scientists on the move: tracing scientists’ mobility and its spatial distribution” Miguélez, E.; Moreno, R.; Suriñach, J.

WP 2009/15 “The First Privatization Policy in a Democracy: Selling State-Owned Enterprises in 1948-1950 Puerto Rico” Bel, G.

WP 2009/14 “Appropriate IPRs, Human Capital Composition and Economic Growth” Manca, F.

WP 2009/13 “Human Capital Composition and Economic Growth at a Regional Level” Manca, F.

WP 2009/12 “Technology Catching-up and the Role of Institutions” Manca, F.

WP 2009/11 “A missing spatial link in institutional quality” Claeys, P.; Manca, F.

WP 2009/10 “Tourism and Exports as a means of Growth” Cortés-Jiménez, I.; Pulina, M.; Riera i Prunera, C.; Artís, M.

WP 2009/09 "Evidence on the role of ownership structure on firms' innovative performance” Ortega-Argilés, R.; Moreno, R.

WP 2009/08 “¿Por qué se privatizan servicios en los municipios (pequeños)? Evidencia empírica sobre residuos sólidos y agua” Bel, G.; Fageda, X.; Mur, M.

WP 2009/07 “Empirical analysis of solid management waste costs: Some evidence from Galicia, Spain” Bel, G.; Fageda, X.

WP 2009/06 “Intercontinental fligths from European Airports: Towards hub concentration or not?” Bel, G.; Fageda, X.

WP 2009/05 “Factors explaining urban transport systems in large European cities: A cross-sectional approach” Albalate, D.; Bel, G.

WP 2009/04 "Regional economic growth and human capital: the role of overeducation” Ramos, R.; Suriñach, J.; Artís, M.

WP 2009/03 “Regional heterogeneity in wage distributions. Evidence from Spain” Motellón, E.; López-Bazo, E.; El-Attar, M.

WP 2009/02 "Modelling the disability severity score in motor insurance claims: an application to the Spanish case” Santolino, M.; Boucher, J.P.

WP 2009/01 “Quality in work and aggregate productivity” Royuela, V.; Suriñach, J.

WP 2008/16 “Intermunicipal cooperation and privatization of solid waste services among small municipalities in Spain” Bel, G.; Mur, M.

WP 2008/15 "Similar problems, different solutions: Comparing refuse collection in the Netherlands and Spain” Bel, G.; Dijkgraaf, E.; Fageda, X.; Gradus, R.

WP 2008/14 "Determinants of the decision to appeal against motor bodily injury settlements awarded by Spanish trial courts” Santolino, M

WP 2008/13 "Does social capital reinforce technological inputs in the creation of knowledge? Evidence from the Spanish regions” Miguélez, E.; Moreno, R.; Artís, M.

WP 2008/12 “Testing the FTPL across government tiers” Claeys, P.; Ramos, R.; Suriñach, J.

WP 2008/11 “Internet Banking in Europe: a comparative analysis” Arnaboldi, F.; Claeys, P.

WP 2008/10 “Fiscal policy and interest rates: the role of financial and economic integration” Claeys, P.; Moreno, R.; Suriñach, J.

WP 2008/09 “Health of Immigrants in European countries” Solé-Auró, A.; M.Crimmins, E. 
WP 2008/08

WP 2008/07

WP 2008/06

WP 2008/05

WP 2008/04

WP 2008/03

WP 2008/02

WP 2008/01

WP 2007/19

WP 2007/18

WP 2007/17

WP 2007/16

WP 2007/15

WP 2007/14

WP 2007/13

WP 2007/12

WP 2007/11

WP 2007/10

WP 2007/09

WP 2007/08

WP 2007/07

WP 2007/06

WP 2007/05

“The Role of Firm Size in Training Provision Decisions: evidence from Spain” Castany, L.

"Forecasting the maximum compensation offer in the automobile BI claims negotiation process" Ayuso, M.; Santolino, M.

"Prediction of individual automobile RBNS claim reserves in the context of Solvency II" Ayuso, M.; Santolino, M.

"Panel Data Stochastic Convergence Analysis of the Mexican Regions” Carrion-i-Silvestre, J.L.; German-Soto, V.

“Local privatization, intermunicipal cooperation, transaction costs and political interests: Evidence from Spain” Bel, G.; Fageda, X.

"Choosing hybrid organizations for local services delivery: An empirical analysis of partial privatization” Bel, G.; Fageda, X.

“Motorways, tolls and road safety. Evidence from European Panel Data” Albalate, D.; Bel, G.

"Shaping urban traffic patterns through congestion charging: What factors drive success or failure?" Albalate, D.; Bel, G.

“La distribución regional de la temporalidad en España. Análisis de sus determinantes” Motellón, E.

“Regional returns to physical capital: are they conditioned by educational attainment?” López-Bazo, E.; Moreno, R.

"Does human capital stimulate investment in physical capital? evidence from a cost system framework” López-Bazo, E.; Moreno, R.

"Do innovation and human capital explain the productivity gap between small and large firms?" Castany, L.; López-Bazo, E.; Moreno, R.

“Estimating the effects of fiscal policy under the budget constraint” Claeys, P.

“Fiscal sustainability across government tiers: an assessment of soft budget constraints” Claeys, P.; Ramos, R.; Suriñach, J.

"The institutional vs. the academic definition of the quality of work life. What is the focus of the European Commission?” Royuela, V.; López-Tamayo, J.; Suriñach, J.

“Cambios en la distribución salarial en españa, 1995-2002. Efectos a través del tipo de contrato” Motellón, E.; López-Bazo, E.; El-Attar, M.

“EU-15 sovereign governments’ cost of borrowing after seven years of monetary union” GómezPuig, M..

“Another Look at the Null of Stationary Real Exchange Rates: Panel Data with Structural Breaks and Cross-section Dependence” Syed A. Basher; Carrion-i-Silvestre, J.L.

"Multicointegration, polynomial cointegration and $\mathrm{I}(2)$ cointegration with structural breaks. An application to the sustainability of the US external deficit” Berenguer-Rico, V.; Carrion-i-Silvestre, J.L.

"Has concentration evolved similarly in manufacturing and services? A sensitivity analysis” RuizValenzuela, J.; Moreno-Serrano, R.; Vaya-Valcarce, E.

"Defining housing market areas using commuting and migration algorithms. Catalonia (Spain) as an applied case study” Royuela, C.; Vargas, M.

"Regulating Concessions of Toll Motorways, An Empirical Study on Fixed vs. Variable Term Contracts” Albalate, D.; Bel, G.

"Decomposing differences in total factor productivity across firm size” Castany, L.; Lopez-Bazo, E.; Moreno, R. 
WP 2007/04

WP 2007/03

WP 2007/02

WP 2007/01

WP 2006/10

WP 2006/09

WP 2006/08

WP 2006/07

WP 2006/06

WP 2006/05

WP 2006/04

WP 2006/03

WP 2006/02

WP 2006/01

“Privatization and Regulation of Toll Motorways in Europe” Albalate, D.; Bel, G.; Fageda, X.

"Is the influence of quality of life on urban growth non-stationary in space? A case study of Barcelona” Royuela, V.; Moreno, R.; Vayá, E.

“Sustainability of EU fiscal policies. A panel test” Claeys, P.

"Research networks and scientific production in Economics: The recent spanish experience" Duque, J.C.; Ramos, R.; Royuela, V.

“Term structure of interest rate. European financial integration” Fontanals-Albiol, H.; Ruiz-Dotras, E.; Bolancé-Losilla, C.

"Patrones de publicación internacional (ssci) de los autores afiliados a universidades españolas, en el ámbito económico-empresarial (1994-2004)” Suriñach, J.; Duque, J.C.; Royuela, V.

“Supervised regionalization methods: A survey” Duque, J.C.; Ramos, R.; Suriñach, J.

“Against the mainstream: nazi privatization in 1930s germany” Bel, G.

"Economía Urbana y Calidad de Vida. Una revisión del estado del conocimiento en España” Royuela, V.; Lambiri, D.; Biagi, B.

"Calculation of the variance in surveys of the economic climate” Alcañiz, M.; Costa, A.; Guillén, M.; Luna, C.; Rovira, C.

"Time-varying effects when analysing customer lifetime duration: application to the insurance market” Guillen, M.; Nielsen, J.P.; Scheike, T.; Perez-Marin, A.M.

“Lowering blood alcohol content levels to save lives the european experience” Albalate, D.

"An analysis of the determinants in economics and business publications by spanish universities between 1994 and 2004” Ramos, R.; Royuela, V.; Suriñach, J.

“Job losses, outsourcing and relocation: empirical evidence using microdata” Artís, M.; Ramos, R.; Suriñach, J. 
